\title{
Pharmacology and therapeutic role of inorganic nitrite and nitrate in vasodilatation
}

\author{
J.C. Bailey ${ }^{\text {a }}$, M. Feelisch ${ }^{\text {b }}$,.D. Horowitz ${ }^{c}$, M.P. Frenneaux ${ }^{\mathrm{d}}$, M. Madhani ${ }^{\mathrm{a}, *}$ \\ a Centre for Cardiovascular Sciences, College of Medical and Dental Sciences, University of Birmingham, UK \\ b Clinical and Experimental Sciences, Faculty of Medicine, University of Southampton, Southampton, UK \\ c The Queen Elizabeth Hospital, Adelaide, Australia \\ d School of Medicine and Dentistry, University of Aberdeen, Aberdeen, UK
}

\section{A R T I C L E I N F O}

Available online 30 June 2014

\section{Keywords:}

Nitrate

Nitrite

Nitric oxide

Vasodilatation

Heart failure

\begin{abstract}
A B S T R A C T
Nitrite has emerged as an important bioactive molecule that can be biotransformed to nitric oxide (NO) related metabolites in normoxia and reduced to NO under hypoxic and acidic conditions to exert vasodilatory effects and confer a variety of other benefits to the cardiovascular system. Abundant research is currently underway to understand the mechanisms involved and define the role of nitrite in health and disease. In this review we discuss the impact of nitrite and dietary nitrate on vascular function and the potential therapeutic role of nitrite in acute heart failure.
\end{abstract}

(c) 2014 Elsevier Inc. All rights reserved.

\section{Contents}

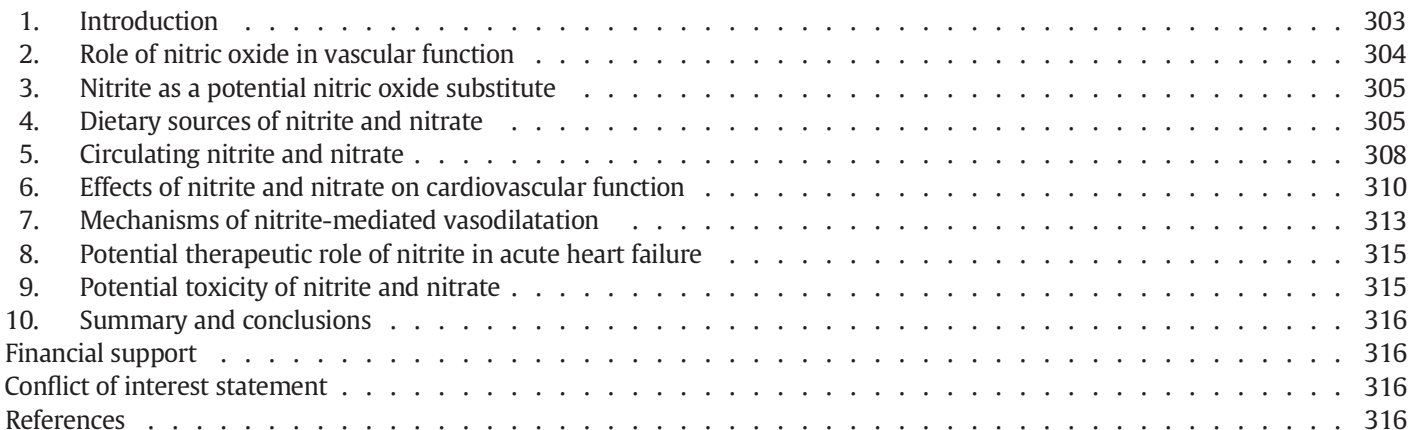

Abbreviations: AHF, acute heart failure; ALDH2, mitochondrial aldehyde dehydrogenase; $\mathrm{BP}$, blood pressure; cGMP, cyclic guanosine monophosphate; CHF, congestive heart failure; CVD, cardiovascular disease; DBP, diastolic blood pressure; deoxyHb, deoxyhemoglobin; eNOS, endothelial nitric oxide synthase; FBF, forearm blood flow; FBF-R, forearm blood flow ratio; FMD, flow mediated dilatation; GTN, glyceryl trinitrate; Hb, hemoglobin; iNOS, inducible nitric oxide synthase; MAP, mean arterial pressure; Mb, myoglobin; NO, nitric oxide; nNOS, neuronal nitric oxide synthase; NOS, nitric oxide synthase; $\mathrm{O}_{2}^{-}$, superoxide; $\mathrm{ONOO}^{-}$ peroxynitrite; oxyHb, oxyhemoglobin; RBC, red blood cell; ROS, reactive oxygen species; SAP, systemic arterial pressure; SBP, systolic blood pressure; sGC, soluble guanylate cyclase; UVA, ultraviolet A; XO, xanthine oxidase; XOR, xanthine oxidoreductase.

* Corresponding author at: Centre for Cardiovascular Sciences, College of Medical and Dental Sciences, University of Birmingham, B15 2TT, UK. Tel.: +44 1214146897.

E-mail address: m.madhani@bham.ac.uk (M. Madhani).

\section{Introduction}

Cardiovascular disease (CVD) is the leading cause of death worldwide accounting for $\sim 30 \%$ of all global deaths (Global status report on non-communicable diseases 2010. Geneva, World Health Organization, 2011). The number of people who will die from CVD, mainly from heart disease and stroke, are projected to increase and reach 23.3 million by 2030 (Mathers \& Loncar, 2006). Despite major advances in the treatment of patients with CVD, the morbidity and mortality associated with CVD is high, and there remains significant space for improvement in new therapeutic interventions. With more potentially promising candidate therapeutics on the horizon, it is particularly important to test 
these new treatments in a clinical setting in order to improve the outcome for CVD patients through application of more effective therapies.

The vascular endothelium is involved in many aspects of cardiovascular health, including regulating vascular tone, hemostasis, thrombosis, permeability and cell adhesion (Hirase \& Node, 2012; Padilla et al., 2014). The endothelium releases vasodilatory substances including nitric oxide (NO), prostacyclin, C-type natriuretic peptide and endothelium-derived hyperpolarizing factor, as well as vasoconstrictors including endothelin-1, angiotensin II and thromboxane $A_{2}$ (Needleman et al., 1976; Moncada \& Vane, 1981; Vanhoutte \& Katusic, 1988; Yanagisawa et al., 1988; Danser et al., 1994). In the healthy endothelium, a balanced production of these factors plays an important preventative role against vascular disease. However endothelial dysfunction disturbs this balance and is associated with an increased risk of development of CVD, such as atherogenesis, increased arterial stiffness (arteriosclerosis) and associated hypertension.

\section{Role of nitric oxide in vascular function}

The discovery in the 1980s that NO could be produced endogenously in the vasculature and exert vasodilatory effects led to a plethora of studies which demonstrated its pleotropic effects including control of blood pressure (BP) and vascular tone, neurotransmission and memory formation, and host defence mechanisms. (Murad et al., 1978; Furchgott \& Zawadski, 1980; Ignarro et al., 1987; Moncada et al., 1988; Loscalzo \& Welch, 1995; Ignarro, 1999). NO is produced by a family of enzymes known as NO synthases (NOS) (Michel \& Feron, 1997) utilizing the substrate L-arginine, molecular oxygen and nicotinamide adenine dinucleotide phosphate (Palmer et al., 1988). Three different isoforms of NOS have been identified. Two of these are constitutively expressed in cells and synthesise NO in response to increased intracellular calcium concentrations (Mayer et al., 1989; Mulsch et al., 1989; Moncada \& Palmer, 1990). The constitutive enzymes are known as neuronal NOS (nNOS or NOS I) and endothelial NOS (eNOS or NOS III) (Michel \& Feron, 1997). The third isoform, termed inducible NOS (iNOS or NOS II), is expressed in response to cytokines and other inflammatory factors in a variety of cells including macrophages, neutrophils, cardiac myocytes and endothelial cells (Szabo et al., 1994) and produces NO independent of changes in intracellular calcium concentration. More recently it has become clear, however, that the production of either constitutive NOS isoform can also be induced under certain conditions, and that some tissues express low levels of iNOS already constitutively. Under normal physiological conditions low levels of NO produced by eNOS function as an important regulatory messenger and maintain vessel tone (Amezcua et al., 1989; Loscalzo \& Welch, 1995). NO-induced vasodilatation is mediated by activation of soluble guanylate cyclase (sGC), which converts guanosine triphosphate into cyclic guanosine monophosphate (cGMP), and subsequently relaxes vascular smooth muscle (Ignarro et al., 1981).

When NO is produced at elevated levels, such as from iNOS during septic shock, NO can also have cytotoxic effects (Szabo et al., 1993). While lower levels of constitutively produced NO are involved in the regulation of mitochondrial activity by competing with oxygen at the level of complex IV of the respiratory chain (Erusalimsky \& Moncada, 2007), higher concentrations of NO have been shown to persistently inhibit mitochondrial function by nitrosylation of electron chain complexes, in particular complex I (Clementi et al., 1998), and to cause DNA damage (Delaney et al., 1993; deRojas-Walker et al., 1995). Endothelial dysfunction is apparent in conditions such as hypertension, heart failure, coronary artery disease, and atherosclerosis (Cai \& Harrison, 2000; Vanhoutte, 2009; de Berrazueta et al., 2010). During these pathophysiological conditions, eNOS-dependent conversion of L-arginine to NO is impaired and thus NO bioavailability is reduced, concurrent with decrease in NO-mediated vasorelaxation (Shimokawa et al., 1991; Pou et al., 1992; Harrison, 1997; Wilcox et al., 1997). Enhanced degradation of NO through scavenging by reactive oxygen species (ROS), together with a reduction in production via eNOS, has also been shown to be involved in reducing NO bioavailability (Harrison, 1997).

NO scavenging by ROS (in particular superoxide, $\mathrm{O}_{2}^{-}$) is normally controlled through a well-balanced production of NO and ROS (Cai \& Harrison, 2000). However during pathological conditions when the production of NO decreases, the balance is perturbed (Griendling \& Fitzgerald, 2003). Superoxide reacts with NO to form peroxynitrite $\left(\mathrm{ONOO}^{-}\right.$) (Burney et al., 1999). Unlike NO, $\mathrm{ONOO}^{-}$is a potent prooxidant which has been demonstrated to play a role in initiating lipid peroxidation in both membranes and lipoproteins (Radi et al., 1991; Rubbo et al., 1994; Thomas et al., 1998). Consequently, $\mathrm{ONOO}^{-}$-modified low density lipoprotein has been shown to be involved in the accumulation of cholesteryl esters in the fatty streaks characteristic of atherosclerosis (Darley-Usmar et al., 1992; Guy et al., 2001).

Endothelial eNOS function may also become compromised as a result of increased oxidative stress. In atherosclerosis, for example, the flow of electrons from the reductase domain of eNOS to the oxidase domain (where L-arginine is oxidized) may become uncoupled from $\mathrm{NO}$ production. Under these conditions, the enzyme produces $\mathrm{O}_{2}^{-}$or $\mathrm{ONOO}^{-}$in place of $\mathrm{NO}$, a process referred to as "eNOS uncoupling". Uncoupling with a concomitant reduction in NO production occurs primarily when eNOS becomes monomeric (normally functional eNOS is a dimer) (Zou et al., 2004; Forstermann \& Munzel, 2006) and dissociation and/or oxidation of the eNOS cofactor tetrahydrobiopterin has been suggested to play a key role in uncoupling (Bendall et al., 2005). Tetrahydrobiopterin availability is thought to be an important regulator in activity and uncoupling of eNOS (Bendall et al., 2005). A recent study in diabetes-induced mice suggests that tetrahydrobiopterin oxidation leads to eNOS uncoupling and dysfunction, with exogenous administration of tetrahydrobiopterin promoting eNOS dimerization and normalisation of eNOS function (Abudukadier et al., 2013). Uncoupling of eNOS has been demonstrated in human arteries and veins concomitant with an increase in $\mathrm{O}_{2}^{-}$production (Margaritis et al., 2013). Increases in $\mathrm{O}_{2}^{-}$production with consecutive endothelial dysfunction have been attributed to eNOS uncoupling (Vasquez-Vivar et al., 1998), enhanced activity of NADPH oxidase (an enzyme whose primary function is to produce $\mathrm{O}_{2}^{-}$) and xanthine oxidase (Jacobson et al., 2007).

Independent of oxidative stress and in addition to situations where the availability of the NOS substrate L-arginine may be compromised, a number of methylated arginine derivatives such as asymmetric dimethylarginine act as endogenous inhibitors of NOS and thus of NO generation (Böger, 2003). Asymmetric dimethylarginine concentrations in plasma and tissues tend to increase in particular in patients with heart and renal failure, contributing to risk of adverse outcomes in such individuals (Visser et al., 2010).

Thus, endothelial dysfunction can be a result of several different abnormalities affecting either production or availability of NO, and under many pathophysiological conditions it is possibly a multifactorial process. Therefore, in most cases no causative treatment option will be available. An attractive alternative to rescuing compromised endothelial function by correcting the true cause of the malfunction is administration of an alternative source of NO. Current treatment options for conditions such as angina, myocardial infarction, and heart failure include administration of organic nitrates, for example glyceryl trinitrate (GTN) as a source of NO, causing coronary vasodilatation (Marsh \& Marsh, 2000). However, undesirable side effects including a throbbing headache and orthostatic problems as well as tolerance development (limiting drug efficacy when administered for a prolonged period of time) have led to an intense search for superior treatment options. As judged by the outcome of several animal experimental studies, inorganic nitrite $\left(\mathrm{NO}_{2}^{-}\right)$administration may hold promise for the treatment of conditions associated with endothelial dysfunction by improving vascular function following biotransformation to NO; if found to be of value in 
human trials as well, it might become an attractive treatment alternative to organic nitrates in the future.

In this review, we discuss nitrite as a potential NO substitute, the mechanisms involved in nitrate bioactivity and the role of nitrite in cardiovascular health and function.

\section{Nitrite as a potential nitric oxide substitute}

The nitrate-nitrite-NO pathway has been proposed as an alternative pathway for NO generation (Lundberg et al., 2008). NO produced through this pathway has been proposed to represent a NOSindependent alternative to the classical pathway in which NO is produced by oxidation of L-arginine in a reaction catalyzed by NOS (Lundberg et al., 2008). Under normal physiological pH and oxygen tension, nitrite is an endogenous substance produced via the oxidation of NO (in cells by cytochrome C oxidase (Torres et al., 2000), in blood principally by ceruloplasmin; Shiva et al., 2006), and for many years nitrite was simply considered a relatively inert metabolic end-product of NO. However in the past decade, it has become apparent that under certain conditions nitrite exerts potent biological effects, and several research groups have identified that - particularly at low $\mathrm{pH}$ and oxygen tension - nitrite is reduced by various nitrite reductases to NO (Cosby et al., 2003; Webb et al., 2004; Rassaf et al., 2007; Shiva et al., 2007a; Feelisch et al., 2008; Webb et al., 2008a; Aamand et al., 2009; Totzeck et al., 2012a). Table 1 summarises various animal studies that have evaluated the efficacy of nitrite as a vasodilator and/or BP lowering agent. In vivo, nitrite is readily oxidized to nitrate $\left(\mathrm{NO}_{3}^{-}\right)$by cellular and acellular processes, and the latter can be reduced back to nitrite via mechanisms involving the commensal bacterial flora of the oral cavity and the gut as well as reduction by xanthine oxidoreductase (XOR) in the host tissues (Lundberg et al., 2009). This had led to the conceptualisation that a 'nitrogen oxide cycle' exists by which dietary sources of nitrite and nitrate mix in with nitrite and nitrate produced by the oxidation of endogenous NO, suggesting a common circulating pool contributes to bodily NO production.

An important physiological role for the nitrate-nitrite-NO pathway is increasingly becoming apparent in the literature as its activity under various conditions is being uncovered. It has been shown by a number of research groups that nitrite-derived bioactivity is cardioprotective by minimising cell death by apoptosis (Webb et al., 2004; Duranski et al., 2005; Dezfulian et al., 2007; Shiva et al., 2007a, 2007b; Tripatara et al., 2007), exerts anti-aggregatory effects (Srihirun et al., 2012; Corti et al., 2013; Park et al., 2013; Velmurugan et al., 2013), inhibits hypoxic and inflammatory pulmonary arterial hypertension (Baliga et al., 2012; Sparacino-Watkins et al., 2012; Bueno et al., 2013), and that it increases forearm blood flow (FBF) and decreases BP by acting as a vasodilator (Cosby et al., 2003; Dejam et al., 2007; Maher et al., 2008). In addition, nitrate has been shown to improve exercise performance by reducing the oxygen cost of exercise in skeletal muscle (Larsen et al., 2011). Since this profile of action resembles that of NO (and the latter can be measured as a reaction product under specific reaction conditions) it is widely believed that NO is the active principle that underpins most if not all of the actions of nitrite (and nitrate). However, to the best of our knowledge, this has not been unequivocally demonstrated. In this review, we shall focus on the vasodilator effects of nitrite and dietary nitrate, together with the therapeutic potential of nitrite in acute heart failure (AHF).

\section{Dietary sources of nitrite and nitrate}

\subsection{Nitrate and conversion to nitrite}

Nitrate $\left(\mathrm{NO}_{3}^{-}\right)$is a ubiquitous constituent of our environment and plays an essential role in the global nitrogen cycle. Symbiotic Rhizobia bacteria located in the root nodules of leguminous plants can fix atmospheric nitrogen and hydrogen to produce ammonia which can be transported into the soil through plant roots, or by decomposition (Gilchrist et al., 2010). The ammonia can be converted into nitrite by denitrifying Nitrosomonas bacteria (and ammonia oxidizing Archaea) in the soil and further to nitrate by Nitrobacter. Nitrate can be taken up from the soil through transporter channels in plant root cells, providing a source of nitrogen for amino acids, proteins and nucleotides essential for growth and development (Wang et al., 2012). The genetic makeup of the plant and thus the degree of nitrate influx and efflux via transporter channels can affect the nitrate content of the plant (Wang et al., 2012). In addition, there are several environmental impacts affecting the degree of nitrogen fixation, including temperature, precipitation, soil type and the extent of agricultural fertilizer use, and the intensity of exposure to sunlight all of which can have an impact on the nitrate content of plants (Seljasen et al., 2012).

\subsection{Dietary sources of nitrate}

Green leafy vegetables are the major source of dietary nitrate. The highest reported nitrate content is found in rocket (arugula; range 963-4305 mg nitrate/kg) (Santamaria et al., 1999), followed by radish (range 1117-2993 mg nitrate $/ \mathrm{kg}$ ) (Santamaria et al., 1999), spinach (range 961-2453 mg nitrate/kg) (Koh et al., 2012), beetroot (range 644-1800 mg nitrate/kg) (Tamme et al., 2006) and lettuce (range 428-1766 mg nitrate/kg depending on type) (Santamaria et al., 1999). Cured meats are also a source of dietary nitrates and nitrites through the use of potassium and sodium nitrate and nitrite as curing/preserving agents in these products (Binkerd \& Kolari, 1975; Kim \& Conca, 1990). Drinking water is another source of nitrate (Knobeloch et al., 2013; Nemčić-Jurec et al., 2013); the concentration of nitrate in drinking water will vary according to geographical location, regional rules regarding safe levels of nitrate in tap water, or the consumption of bottled water (Espejo-Herrera et al., 2013).

\subsection{Route of dietary nitrate after consumption}

Tracer studies with the stable nitrogen isotope ${ }^{15} \mathrm{~N}$ revealed that about $60 \%$ of an oral ${ }^{15} \mathrm{~N}$-nitrate dose ingested is excreted via the kidneys within the following $48 \mathrm{~h}$; the fate of the remainder is unclear and assumed to be subject to metabolic transformation to other nitrogen-containing species (Wagner et al., 1984). About 25\% of the circulating pool of nitrate is actively taken up from blood via an anion exchange channel called sialin (Qin et al., 2012) and secreted by the salivary glands into saliva (Lundberg et al., 2008). The salivary nitrate is reduced to nitrite by commensal bacteria (Actinomyces and Veillonella spp.) residing on the surface of the tongue (Tannenbaum et al., 1976; Pannala et al., 2003; Doel et al., 2005). Nitrite is then swallowed into the stomach; in this strongly acidic environment nitrite is protonated to form nitrous acid $\left(\mathrm{HNO}_{2} ; \mathrm{pK}_{\mathrm{a}} 3.15\right.$; the $\mathrm{pK}_{\mathrm{a}}$ is the $\mathrm{pH}$ at which $50 \%$ of the acid is dissociated), and can spontaneously give rise to the generation of $\mathrm{NO}$ through the following sequence of reactions: $2 \mathrm{HNO}_{2} \rightarrow \mathrm{H}_{2} \mathrm{O}+$ $\mathrm{N}_{2} \mathrm{O}_{3}$ and $\mathrm{N}_{2} \mathrm{O}_{3} \leftrightarrow \mathrm{NO}+\mathrm{NO}_{2}$ (Butler \& Feelisch, 2008), or re-enters the circulation as nitrite (Benjamin et al., 1994; Lundberg et al., 1994). This cycle is known as the 'enterosalivary recirculation pathway' of nitrate.

Several studies have highlighted the importance of oral bacteria flora in the reduction of nitrate to nitrite. In earlier studies by Lundberg and Govoni (2004), the authors showed that avoiding swallowing after nitrate ingestion can abrogate increases in plasma nitrite (Lundberg \& Govoni, 2004). In 2008 Govoni and colleagues expanded this work by studying the effects of commercially available antibacterial mouthwash on salivary and plasma levels of nitrate and nitrite following an oral intake of dietary nitrate (sodium nitrate) in healthy subjects. The authors reported that rinsing the mouth with antibacterial mouthwash prior to ingestion of nitrate reduces the conversion to nitrite in the saliva and attenuates the rise in plasma nitrite (Govoni et al., 2008). To corroborate these findings further, Petersson et al. (2009) explored the role of oral commensal bacteria in bioactivation of dietary nitrate to nitrite and 
Table 1

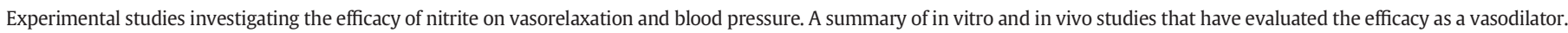

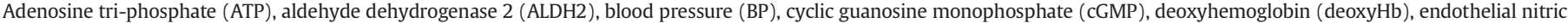

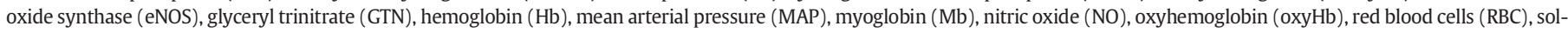
uble guanylate cyclase (sGC), systemic arterial pressure (SAP), xanthine oxidase (XO), xanthine oxidoreductase (XOR).

\begin{tabular}{|c|c|c|c|c|c|}
\hline Species & Condition/model & Nitrite reductase & $\begin{array}{l}\text { Dose/route/timing administration } \\
\text { of nitrite }\end{array}$ & Results & Reference \\
\hline Mouse & $\begin{array}{l}\text { Hypertension model. Wild type } \\
\text { compared to eNOS }-/- \text { mice }\end{array}$ & $\begin{array}{l}\text { eNOS from RBC } \\
\text { (non-endothelial) }\end{array}$ & Endogenous systemic nitrite levels & $\begin{array}{l}\text { eNOS-/- mice displayed lower plasma } \\
\text { nitrite concentrations compared to wild } \\
\text { type. Provides evidence that circulating } \\
\text { blood eNOS plays a role in nitrite } \\
\text { homeostasis and BP regulation during } \\
\text { physiological conditions }\end{array}$ & $\begin{array}{l}\text { (Wood et al., } \\
\text { 2013) }\end{array}$ \\
\hline Rat & $\begin{array}{l}\text { Hypertension model. Used } \\
\text { spontaneous hypertensive \& } \\
\text { normotensive Wistar Kyoto rats }\end{array}$ & $\begin{array}{l}\text { XOR derived from } \\
\text { RBCS }\end{array}$ & $\begin{array}{l}\text { Potassium nitrite administered } \\
\text { as bolus doses between } 1- \\
30,000 \times 10-9 \mathrm{~mol} / \mathrm{kg}\end{array}$ & $\begin{array}{l}\text { Nitrite decreased BP in a dose- } \\
\text { dependent manner. The effect of nitrite } \\
\text { was greater in spontaneously hyperten- } \\
\text { sive rats compared to normotensive and } \\
\text { was abolished with allopurinol (XOR in- } \\
\text { hibitor). The study showed that this ef- } \\
\text { fect was associated with an increase in } \\
\text { erythrocytic XOR expression but not in } \\
\text { the blood vessel wall }\end{array}$ & $\begin{array}{l}\text { (Ghosh et al., } \\
\text { 2013) }\end{array}$ \\
\hline Mouse & $\begin{array}{l}\text { Assessment of hypoxia vasodilatation } \\
\text { in Mb wild type and deficient mice }\end{array}$ & $\mathrm{Mb}$ & $\begin{array}{l}\text { Assessed endogenous and exogenous } \\
\text { nitrite. For exogenous studies } 1.67 \text { or } \\
16.7 \mu \mathrm{mol} / \mathrm{kg} \text { was used }\end{array}$ & $\begin{array}{l}\text { Mb expression in vascular smooth } \\
\text { muscle contributes to nitrite-mediated } \\
\text { hypoxic vasodilatation ex vivo and } \\
\text { in vivo. This effect was mediated via Mb- } \\
\text { induced activation of NO/sGC/cGMP } \\
\text { pathway }\end{array}$ & $\begin{array}{l}\text { (Totzeck et al., } \\
\text { 2012a) }\end{array}$ \\
\hline Rat & $\begin{array}{l}\text { Normotensive compared to } \\
\text { hypertensive rats. Assessed whether } \\
\text { gastric pH reduced hypotensive effects }\end{array}$ & - & $\begin{array}{l}2 \text { protocols used: } \\
\text { (1) oral (gavage) administration } \\
\text { sodium nitrite }(1-45 \mathrm{mg} / \mathrm{kg}) \\
\text { compared with } \\
\text { (2) intravenous sodium nitrite } \\
(1-15 \mathrm{mg} / \mathrm{kg})\end{array}$ & $\begin{array}{l}\text { Increased gastric pH caused by } \\
\text { omeprazole reduced the hypotensive } \\
\text { effect of nitrite in both normotensive and } \\
\text { L-NAME-hypertensive rats. The study } \\
\text { concluded that the hypotensive effect of } \\
\text { sodium nitrite was partly due to biocon- } \\
\text { version to NO under acidic conditions of } \\
\text { the stomach }\end{array}$ & $\begin{array}{l}\text { (Pinheiro et al., } \\
\text { 2012) }\end{array}$ \\
\hline Mouse & $\begin{array}{l}\text { Assessed the effects of dietary nitrate } \\
\text { on XOR and eNOS in pulmonary hy- } \\
\text { pertension model }\end{array}$ & eNOS and XOR & $\begin{array}{l}\text { Supplementation of drinking water } \\
\text { with either potassium nitrate } \\
(15 \mathrm{mmol} / \mathrm{l} \text { or } 45 \mathrm{mmol} / \mathrm{l}) \text { or } \\
\text { potassium nitrite }(0.6 \mathrm{mmol} / \mathrm{l})\end{array}$ & $\begin{array}{l}\text { Dietary nitrate, but to lesser extent } \\
\text { dietary nitrite, causes pulmonary } \\
\text { dilatation and prevents vascular } \\
\text { remodelling and right ventricular } \\
\text { hypertrophy. These effects were } \\
\text { dependent on eNOS and XOR reduction } \\
\text { of nitrite to NO }\end{array}$ & $\begin{array}{l}\text { (Baliga et al., } \\
\text { 2012) }\end{array}$ \\
\hline Ovine & $\begin{array}{l}\text { Assessed the effects of nitrite on } \\
\text { pulmonary and systemic arterial } \\
\text { vascular resistance in newborn lambs }\end{array}$ & DeoxyHb & $\begin{array}{l}\text { Inhalation of sodium nitrite via } \\
\text { nebulizer }(0.87 \mathrm{~mol} / \mathrm{l}) \text { compared } \\
\text { to intravascular nitrite infusion } \\
5 \mathrm{mg} / \mathrm{kg} / \mathrm{h}\end{array}$ & $\begin{array}{l}\text { Inhaled nitrite elicited pulmonary } \\
\text { vasodilatation through NO mediated } \\
\text { mechanism. Intravascular nitrite did not } \\
\text { elicit pulmonary vasodilatation. Inhaled } \\
\text { nitrite produces NO in the airway and } \\
\text { parenchymal lung tissue to mediate va- } \\
\text { sodilatation and this was independent of } \\
\text { deoxyHb in the pulmonary circulation }\end{array}$ & $\begin{array}{l}\text { (Blood et al., } \\
\text { 2011) }\end{array}$ \\
\hline Mouse & $\begin{array}{l}\text { Model of vascular endothelial } \\
\text { dysfunction associated with age using } \\
\text { old ( } 26-28 \text { month) mice compared to } \\
\text { young ( } 4-6 \text { month) mice. }\end{array}$ & - & $\begin{array}{l}\text { Supplementation of sodium nitrite } \\
\text { in drinking water }(50 \mathrm{mg} / \mathrm{l}) \text { for } \\
\text { three weeks }\end{array}$ & $\begin{array}{l}\text { Sodium nitrite restored endothelium- } \\
\text { dependent dilatation in old mice via in- } \\
\text { crease in NO bioavailability. Nitrite re- } \\
\text { versed vascular endothelial dysfunction } \\
\text { associated with age }\end{array}$ & $\begin{array}{l}\text { (Sindler et al., } \\
\text { 2011) }\end{array}$ \\
\hline Mouse & $\begin{array}{l}\text { Assessed the effects of nitrite on } \\
\text { vascular } \mathrm{Mb}\end{array}$ & $\mathrm{Mb}$ & Sodium nitrite & $\begin{array}{l}\text { Vascular Mb plays an essential role in } \\
\text { nitrite-dependent vasodilatation. }\end{array}$ & $\begin{array}{l}\text { (Ormerod et al., } \\
\text { 2011) }\end{array}$ \\
\hline Rat & $\begin{array}{l}\text { Assessed the role of GTN and sodium } \\
\text { nitrite in the pulmonary vascular bed }\end{array}$ & ALDH2 and XOR & $\begin{array}{l}\text { Intravenous injection sodium } \\
\text { nitrite }(10-100 \mu \mathrm{mol} / \mathrm{kg})\end{array}$ & $\begin{array}{l}\text { Administration of GTN or sodium nitrite } \\
\text { caused a decrease in pulmonary and SAP. } \\
\text { Response to GTN or sodium nitrite was } \\
\text { attenuated by cyanamide (ALDH2 inhib- } \\
\text { itor). The effect of sodium nitrite, but not } \\
\text { GTN, was also attenuated by allopurinol } \\
\text { (XOR inhibitor) }\end{array}$ & $\begin{array}{l}\text { (Badejo et al., } \\
\text { 2010) }\end{array}$ \\
\hline Rat & $\begin{array}{l}\text { Assessed the mechanism of nitrite and } \\
\text { RBC-mediated vasodilatation }\end{array}$ & - & $\begin{array}{l}\text { Intravenous injection sodium } \\
\text { nitrite } 10 \mu \mathrm{mol} / \mathrm{kg}\end{array}$ & $\begin{array}{l}\text { Vasodilatation via nitrite could be } \\
\text { mediated through nitrite enhancement } \\
\text { of ATP release from RBC }\end{array}$ & $\begin{array}{l}\text { (Cao et al., } \\
\text { 2009) }\end{array}$ \\
\hline Rabbit & $\begin{array}{l}\text { Assessed the effect of nitrite on NO- } \\
\text { dependent and independent vasodila- } \\
\text { tation pathways during hypoxic con- } \\
\text { ditions }\end{array}$ & $\begin{array}{l}\text { Aldehyde oxidase, } \\
\text { eNOS, XO }\end{array}$ & Nitrite & $\begin{array}{l}\text { During hypoxia, nitrite-induced vasore- } \\
\text { laxation was largely due to nitrite re- } \\
\text { duction by aldehyde oxidase to NO, but } \\
\text { was also partly mediated via the cyclo- } \\
\text { oxygenase pathway. XO or eNOS did not } \\
\text { play a role in this study }\end{array}$ & $\begin{array}{l}\text { (Pinder et al., } \\
\text { 2009) }\end{array}$ \\
\hline Rat & $\begin{array}{l}\text { Effect of carbonic anhydrase on nitrite- } \\
\text { induced vasodilatation during } \\
\text { normoxia and hypoxia }\end{array}$ & Carbonic anhydrase & Sodium nitrite & $\begin{array}{l}\text { Carbonic anhydrase reacts with nitrite to } \\
\text { produce NO during low pH conditions. } \\
\text { This reaction induced vasorelaxation } \\
\text { during normoxic and hypoxic conditions }\end{array}$ & $\begin{array}{l}\text { (Aamand et al., } \\
\text { 2009) }\end{array}$ \\
\hline
\end{tabular}


Table 1 (continued)

\begin{tabular}{|c|c|c|c|c|c|}
\hline Species & Condition/model & Nitrite reductase & $\begin{array}{l}\text { Dose/route/timing administration } \\
\text { of nitrite }\end{array}$ & Results & Reference \\
\hline Rat & $\begin{array}{l}\text { Investigated the importance of oral } \\
\text { microflora and dietary nitrate in } \\
\text { regulation of BP and gastric mucosal } \\
\text { defence }\end{array}$ & - & $\begin{array}{l}\text { Supplementation of drinking water } \\
\text { with either sodium nitrate } 10 \mathrm{mM} \\
(\sim 140 \mathrm{mg} / \mathrm{kg} / \text { day }) \text { or sodium nitrite } \\
1 \mathrm{mM}(\sim 14 \mathrm{mg} / \mathrm{kg} / \text { day })\end{array}$ & $\begin{array}{l}\text { Mouthwash reduced nitrate-reducing } \\
\text { oral bacteria and caused a reduction in } \\
\text { circulating nitrite. BP reduction was ob- } \\
\text { served after nitrate supplementation in } \\
\text { the absence of mouthwash. } \\
\text { Gastroprotective effect of nitrate was re- } \\
\text { duced in rats treated with mouthwash }\end{array}$ & $\begin{array}{l}\text { (Petersson et al., } \\
\text { 2009) }\end{array}$ \\
\hline Rat & $\begin{array}{l}\text { Assessed the role of XOR and ALDH2 in } \\
\text { nitrite-mediated effects on BP in rats }\end{array}$ & XOR and ALDH2 & $\begin{array}{l}\text { Intravenous administration of } \\
\text { sodium nitrite }\end{array}$ & $\begin{array}{l}\text { Nitrite decreased mean SAP. The } \\
\text { decreases in mean SAP in response to } \\
\text { sodium nitrite was attenuated by both } \\
\text { XOR and ALDH } 2 \text { inhibitors. The study } \\
\text { suggested that both XOR and ALDH2 } \\
\text { work in parallel to mediate nitrite con- } \\
\text { version to vasoactive NO }\end{array}$ & $\begin{array}{l}\text { (Golwala et al., } \\
\text { 2009) }\end{array}$ \\
\hline Rat & $\begin{array}{l}\text { Assessed the role of XOR in response to } \\
\text { sodium nitrite in the pulmonary vas- } \\
\text { culature }\end{array}$ & XOR & $\begin{array}{l}\text { Intravenous injection of sodium } \\
\text { nitrite } 10-100 \mu \mathrm{mol} / \mathrm{kg}\end{array}$ & $\begin{array}{l}\text { Intravenous administration of nitrite } \\
\text { decreased pulmonary arterial pressure } \\
\text { and SAP The responses to nitrite was at- } \\
\text { tenuated by allopurinol (XOR inhibitor). } \\
\text { This study suggests that XOR is the major } \\
\text { enzyme reducing nitrite to vasoactive } \\
\text { NO, and that this mechanism is not } \\
\text { modified by hypoxia }\end{array}$ & $\begin{array}{l}\text { (Casey et al., } \\
\text { 2009) }\end{array}$ \\
\hline Canine & $\begin{array}{l}\text { Assessed the physiological effects } \\
\text { of sodium nitrite and determined } \\
\text { whether the effect was influenced } \\
\text { by cell-free plasma Hb during } \\
\text { intravascular hemolysis }\end{array}$ & $\mathrm{Hb}$ & $\begin{array}{l}\text { Intravenous infusion of sodium } \\
\text { nitrite } 27.5 \mathrm{mg} / \mathrm{h} \text { for } 6 \mathrm{~h}\end{array}$ & $\begin{array}{l}\text { Nitrite reductase activity of } \mathrm{Hb} \text { caused an } \\
\text { increased vasodilatory response to } \\
\text { nitrite during low levels of hemolysis }\end{array}$ & $\begin{array}{l}\text { (Minneci et al., } \\
\text { 2008) }\end{array}$ \\
\hline Rat & $\begin{array}{l}\text { Assessed effect of nitrite on BP } \\
\text { in vivo and vasorelaxation in } \\
\text { isolated aorta in vitro }\end{array}$ & $\mathrm{Hb}$ & $\begin{array}{l}\text { In vivo: intravenous injection of } \\
\text { sodium nitrite ( } 10 \mu \mathrm{M}-2 \mathrm{mM})\end{array}$ & $\begin{array}{l}\text { In vivo: Sodium nitrite caused a dose } \\
\text { dependent decrease in BP In vitro: Dur- } \\
\text { ing aerobic conditions, XOR, mitochon- } \\
\text { drial electron transport, cytochrome } \\
\text { P450 and NOS inhibitors did not effect } \\
\text { nitrite-mediated vasorelaxation. The } \\
\text { study suggested that heme proteins and/ } \\
\text { or sGC pathways are involved in nitrite } \\
\text { mediated effects }\end{array}$ & $\begin{array}{l}\text { (Alzawahra et al., } \\
\text { 2008) }\end{array}$ \\
\hline $\begin{array}{l}\text { Non- } \\
\text { human } \\
\text { primates }\end{array}$ & $\begin{array}{l}\text { Assessed the physiological and } \\
\text { pharmacological effects of sodium } \\
\text { nitrite on vasodilatory responses }\end{array}$ & $\mathrm{XOR}$ and deoxyHb & $\begin{array}{l}\text { Sodium nitrite } 12.5 \mu \mathrm{g} / \mathrm{kg} / \mathrm{min} \text { over } \\
24 \mathrm{~h} \text { for } 14 \text { days }\end{array}$ & $\begin{array}{l}\text { Sodium nitrite was a potent vasodilator } \\
\text { at near-physiological concentrations. Ni- } \\
\text { trite was reduced to NO by intravascular } \\
\text { reactions with deoxyHb. In contrast, XOR } \\
\text { inhibition did not attenuate the nitrite- } \\
\text { induced vasodilatation }\end{array}$ & $\begin{array}{l}\text { (Dejam et al., } \\
\text { 2007) }\end{array}$ \\
\hline Rat & $\begin{array}{l}\text { Assessed effect of Hb oxygen } \\
\text { saturation on vasodilatation }\end{array}$ & OxyHb/DeoxyHb & $\begin{array}{l}\text { Sodium nitrite increasing } \\
\text { concentration } 0.01 \text { to } 1000 \mu \mathrm{M}\end{array}$ & $\begin{array}{l}\text { Deoxygenation of Hb was associated } \\
\text { with nitrite-dependent vasodilatation } \\
\text { which was inhibited by NO scavenger (c- } \\
\text { PTIO) under both normoxic and hypoxic } \\
\text { conditions. In contrast, NO dependent } \\
\text { vasodilatation (via NO donor NONOate) } \\
\text { was inhibited by both oxyHb and } \\
\text { deoxyHb suggesting unique interaction } \\
\text { of nitrite with Hb. This study suggested } \\
\text { that NO homeostasis was regulated by } \\
\text { balance in NO scavenging/generating } \\
\text { activity through oxygen saturation of Hb }\end{array}$ & $\begin{array}{l}\text { (Isbell et al., } \\
\text { 2007) }\end{array}$ \\
\hline Rat & $\begin{array}{l}\text { Effect of nitrite dependent } \\
\text { vasodilatation in hypoxia } \\
\text { (in vitro) }\end{array}$ & $\begin{array}{l}\mathrm{Hb}, \mathrm{XO} \text {, mitochon- } \\
\text { drial } \\
b c 1 \text { complex }\end{array}$ & $\begin{array}{l}\text { Sodium nitrite in cumulative } \\
\text { additions } 0.01 \text { to } 300 \mu \mathrm{M}\end{array}$ & $\begin{array}{l}\text { Nitrite induced a concentration } \\
\text { dependent effect on vasodilatation. The } \\
\text { vasoactive effect of nitrite during } \\
\text { hypoxia was attenuated on inhibition of } \\
\text { sGC but was unaffected by inhibition of } \\
\text { xanthine oxidase or the mitochondrial } \\
\text { bc } 1 \text { complex. In addition, deoxygenation } \\
\text { of Hb did not appear to enhance } \\
\text { vasoactivity of nitrite }\end{array}$ & $\begin{array}{l}\text { (Dalsgaard et al., } \\
\text { 2007) }\end{array}$ \\
\hline Rat & $\begin{array}{l}\text { Hypoxic pulmonary vasoconstriction } \\
\text { in isolated perfused lungs }\end{array}$ & $\mathrm{Hb}$ & $\begin{array}{l}\text { Lungs perfused with sodium nitrite } \\
\text { buffer increasing concentration ( } 250 \\
\mathrm{nM} \text { to } 1 \mathrm{mM} \text { ) with or without RBCs }\end{array}$ & $\begin{array}{l}\text { In isolated perfused lungs, low } \\
\text { concentrations of nitrite inhibited } \\
\text { hypoxic pulmonary vasoconstriction, } \\
\text { possibly due to the release of NO rather } \\
\text { than the direct effect of nitrite on vascu- } \\
\text { lar smooth muscle. However, physiolog- } \\
\text { ical concentrations of RBCs and free Hb } \\
\text { prevented nitrite inhibition of hypoxic } \\
\text { pulmonary vasoconstriction thus raising } \\
\text { doubts for the role of RBCs in nitrite- } \\
\text { mediated vasodilatation in the pulmo- } \\
\text { nary circulation }\end{array}$ & $\begin{array}{l}\text { (Deem et al., } \\
\text { 2007) }\end{array}$ \\
\hline
\end{tabular}


Table 1 (continued)

\begin{tabular}{|c|c|c|c|c|c|}
\hline Species & Condition/model & Nitrite reductase & $\begin{array}{l}\text { Dose/route/timing administration } \\
\text { of nitrite }\end{array}$ & Results & Reference \\
\hline Canine & $\begin{array}{l}\text { In vivo model of acute pulmonary } \\
\text { thromboembolism }\end{array}$ & - & $\begin{array}{l}\text { Intravenous infusion of nitrite } \\
(6.75 \mu \mathrm{mol} / \mathrm{kg} \text { over } 15 \mathrm{~min} \text { then at } \\
0.28 \mu \mathrm{mol} / \mathrm{kg} / \mathrm{min} \text { for } 120 \mathrm{~min})\end{array}$ & $\begin{array}{l}\text { Infusion of nitrite increased plasma } \\
\text { nitrite levels with a dose-dependent } \\
\text { decrease in pulmonary vascular } \\
\text { resistance index, systemic vascular } \\
\text { resistance index, and MAP }\end{array}$ & $\begin{array}{l}\text { (Dias-Junior } \\
\text { et al., 2006) }\end{array}$ \\
\hline $\begin{array}{l}\text { Rat and } \\
\text { rabbit }\end{array}$ & $\begin{array}{l}\text { Hypoxic vasodilatation in isolated } \\
\text { thoracic aortas }\end{array}$ & $\mathrm{Hb}$ & Sodium nitrite $0.01-1000 \mu \mathrm{M}$ & $\begin{array}{l}\text { This study showed that nitrite induced } \\
\text { vasodilatation and supported the role } \\
\text { of RBC Hb to redox regulate nitrite } \\
\text { reductase activity during hypoxia }\end{array}$ & $\begin{array}{l}\text { (Crawford et al., } \\
\text { 2006) }\end{array}$ \\
\hline Rat & Hypertension & Hb-NO complex & $\begin{array}{l}\text { Acute: sodium nitrite } \\
(1,3,10 \mathrm{mg} / \mathrm{kg}) \text { by oral gavage. } \\
\text { Chronic: sodium nitrite } \\
\text { supplemented in drinking water } \\
(100 \mathrm{mg} / \mathrm{l} \text { or } 1000 \mathrm{mg} / \mathrm{l})\end{array}$ & $\begin{array}{l}\text { Orally administered nitrite is detectable } \\
\text { in the circulation as HbNO. Nitrite } \\
\text { treatment attenuates L-NAME induced } \\
\text { hypertension in a dose-dependent } \\
\text { manner }\end{array}$ & $\begin{array}{l}\text { (Tsuchiya et al., } \\
\text { 2005) }\end{array}$ \\
\hline Ovine & $\begin{array}{l}\text { Assessed inhaled sodium nitrite by } \\
\text { aerosol in hypoxia-induced pulmonary } \\
\text { hypertension in newborn lambs }\end{array}$ & $\begin{array}{l}\mathrm{Hb} \text { and iron- } \\
\text { nitrosyl-Hb }\end{array}$ & $\begin{array}{l}\text { Inhaled nebulized sodium nitrite } \\
15 \mathrm{mg} / \mathrm{min} \text { for } 20 \mathrm{~min}\end{array}$ & $\begin{array}{l}\text { Pulmonary vasodilatation was elicited } \\
\text { by aerosol nitrite. This was deoxyHb, } \\
\text { pH dependent and associated with } \\
\text { increased blood levels of iron- } \\
\text { nitrosyl-Hb }\end{array}$ & $\begin{array}{l}\text { (Hunter et al., } \\
\text { 2004) }\end{array}$ \\
\hline Rat & $\begin{array}{l}\text { Assessed the role of NO-modified } \mathrm{Hb} \text { in } \\
\text { isolated rat thoracic aortas }\end{array}$ & DeoxyHb & In vitro sodium nitrite & $\begin{array}{l}\text { Sodium nitrite was associated with } \\
\text { reduction of nitrite to NO by deoxyHb } \\
\text { during hypoxic conditions }\end{array}$ & $\begin{array}{l}\text { (Cosby et al., } \\
\text { 2003) }\end{array}$ \\
\hline Swine & $\begin{array}{l}\text { In vitro and ex vivo assessment of } \\
\text { nitrite in isolated perfused and } \\
\text { ventilated pig lungs }\end{array}$ & - & $\begin{array}{l}\text { Lungs: perfusion of buffer } \\
\text { containing } 0.1 \text { and } 1 \mathrm{mmol} / \mathrm{l} \text { nitrite } \\
\text { anions from sodium nitrite }\end{array}$ & $\begin{array}{l}\text { Nitrite anions at physiological } \\
\text { concentrations act as a vasodilator }\end{array}$ & $\begin{array}{l}\text { (Demoncheaux } \\
\text { et al., 2002) }\end{array}$ \\
\hline Rat & $\begin{array}{l}\text { Assessed effect of } \mathrm{pH} \text { on nitrite- } \\
\text { induced vasorelaxation in rat aorta }\end{array}$ & - & $\begin{array}{l}\text { Cumulative addition of sodium } \\
\text { nitrite } 0.5 \text { to } 1000 \mu \mathrm{M}\end{array}$ & $\begin{array}{l}\text { Nitrite induced vasorelaxation, which } \\
\text { was enhanced under acidic conditions } \\
\text { and nitrite-derived NO was generated } \\
\text { in a pH-dependent manner. Vasoactivity } \\
\text { of nitrite was greatly reduced by } \\
\text { inhibition of sGC }\end{array}$ & $\begin{array}{l}\text { (Modin et al., } \\
\text { 2001) }\end{array}$ \\
\hline
\end{tabular}

NO. Rats were treated twice daily with antiseptic mouthwash while they were given nitrate-supplemented drinking water $(10 \mathrm{mmol} / \mathrm{l}$ sodium nitrate) (Petersson et al., 2009). The authors reported a reduction of nitrate-reducing oral bacteria with a consecutive attenuation of circulating nitrite levels and the gastroprotective effects of nitrate. Moreover, nitrite-dependent BP lowering effects of nitrate were abolished, suggesting oral bacteria play an essential role in the regulation of gastrointestinal and cardiovascular function via the bioactivation of salivary nitrate (Petersson et al., 2009). Furthermore, Kapil and colleagues have shown in healthy volunteers that seven days treatment with an antiseptic mouthwash reduces oral nitrite production by up to $90 \%$, with a concomitant decrease in plasma nitrite levels to $25 \%$ of control values (Kapil et al., 2013).

\section{Circulating nitrite and nitrate}

\subsection{Relationship between plasma nitrite and nitrate}

The basal level of nitrite in the plasma of healthy individuals has been measured, with considerable variation between subjects and methods used, with values ranging from a range of $50-150 \mathrm{nmol} / \mathrm{l}$ to almost $1000 \mathrm{nmol} / \mathrm{l}$ (Gladwin et al., 2000; Lauer et al., 2001; Kleinbongard et al., 2003; Rassaf et al., 2003; Govoni et al., 2008). The reason for this variability is not exactly clear but is likely to involve methodological issues such as ongoing uptake by blood cells during the centrifugation process. The majority of basal nitrite originates from the oxidation of NO (Moncada \& Higgs, 1993; Rhodes et al., 1995; Kleinbongard et al., 2003), with the remainder stemming from the metabolic conversion of dietary nitrate. Ingestion of nitrate causes a rapid increase in circulating plasma nitrate within 30 min of consumption; the level of plasma nitrate peaks at $3 \mathrm{~h}$ with levels remaining elevated for up to $24 \mathrm{~h}$ (McKnight et al., 1997; Kapil et al., 2010a). Elevations in plasma nitrate are followed by a delayed increase in plasma nitrite secondary to bioconversion; nitrite levels rise over 1 to $2 \mathrm{~h}$ and form a plateau between 2 and $6 \mathrm{~h}$ after which concentrations decline (McKnight et al., 1997; Kapil et al., 2010a). Further research has demonstrated maximal reduction in BP in humans at 2 to $3 \mathrm{~h}$ after consumption of nitrate, corresponding with the point of peak plasma nitrite concentration (Webb et al., 2008b; Petersson et al., 2009). It has also been suggested that BP reduction by nitrates acts in a dosedependent manner (Kapil et al., 2010a), although it is appreciated now that physiologically, the basal level of nitrite is an important contributor to blood flow regulation.

\subsection{The effect of dietary nitrate on circulatory nitrate and nitrite levels}

The Mediterranean diet is noted for its high content of vegetables, fruit and fish and has been linked to a lower incidence of CVD (Appel et al., 1997; Joshipura et al., 2001; Lundberg et al., 2006; Grosso et al., 2014) and diabetes (Salas-Salvado et al., 2014). The volume of vegetable consumption is notably higher in the Mediterranean diet than the Western diet; for example in the UK the average vegetable consumption per day is estimated at $160 \mathrm{~g}$ (Meah et al., 1994), while the Mediterranean diet contains $\sim 550 \mathrm{~g}$ of vegetables per day (Trichopoulou et al., 2003). In terms of vegetable-provided dietary nitrate, the Mediterranean diet is estimated to contain $400 \mathrm{mg}$ nitrate per day, which is over four times the amount in a typical Western diet (estimated at $77 \mathrm{mg}$ per day) (Raat et al., 2009). The Dietary Approaches to Stop Hypertension (DASH) diet has also been suggested to aid in reduction of CVD, and a review of current dietary recommendations based on the levels of beneficial dietary nitrate and nitrite has recently been suggested (Hord, 2011).

Numerous studies have demonstrated that intake of nitrate-rich vegetables can increase the levels of circulating plasma nitrite (Lundberg et al., 2006; Kapil et al., 2010b; Lidder \& Webb, 2012; Machha \& Schechter, 2012). An acute application of sodium (or potassium) nitrate in water or fruit juice or supplementation of the diet with nitrate has been shown to increase the levels of plasma nitrite (Lundberg \& Govoni, 2004; Larsen et al., 2006; Kapil et al., 2010a). Beetroot juice has a relatively high nitrate content and is frequently used in 
Table 2

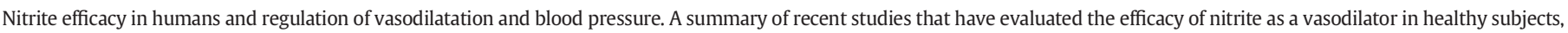

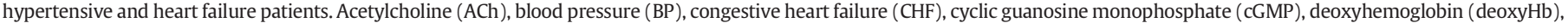

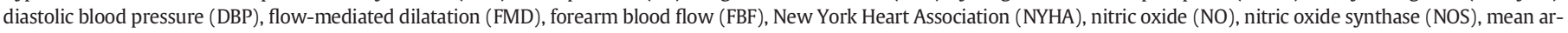
terial pressure (MAP), red blood cells (RBC), systolic blood pressure (SBP), xanthine oxidoreductase (XOR).

\begin{tabular}{lll}
\hline Condition/model & Nitrite reductase & $\begin{array}{l}\text { Dose/route/timing administration } \\
\text { of nitrite }\end{array}$ \\
\hline $\begin{array}{l}\text { Hypertension model. Grade } 1 \\
\text { hypertensive patients }\end{array}$ & XOR derived from RBCs & $\begin{array}{l}\text { Dietary nitrate via } 250 \mathrm{ml} \text { beet } \\
\text { juice containing } ~ 3.5 \mathrm{mmol} \text { nit }\end{array}$ \\
& & \\
& & \\
$\begin{array}{l}\text { CHF patients (NYHA class II-III) } \\
\text { compared to healthy } \\
\text { volunteers. Hemodynamic } \\
\text { assessment of unstressed } \\
\text { forearm venous volume and FBF }\end{array}$ & 30 min intravenous infusion \\
& & $\begin{array}{l}\text { of sodium nitrite } \\
(0.31-7.8 \mu \text { mol/min }) \text { in the } \\
\text { forearm brachial artery }\end{array}$
\end{tabular}

Healthy subjects

Healthy subjects. Assessment of inorganic nitrate on endothelial function by FMD and BP

Healthy subjects

Healthy subjects. Assessment of dietary nitrate and supplementation on $\mathrm{BP}$, and sex differences in response to nitrate

Healthy subjects. Assessed acute and chronic supplementation of nitrate on $\mathrm{BP}$ and exercise

Healthy subjects. Effect of nitrate from Japanese diet on BP

Healthy subjects. Effect of low-dose nitrite on hypoxic pulmonary vasodilatation

Investigated the effects of sodium nitrite on FBF in patients with sickle cell disease. Compared to healthy controls (Cosby et al., 2003)
Dietary nitrate via $200 \mathrm{~g}$ beetroot bread containing $100 \mathrm{~g}$ beetroot (1.1 mmol nitrate) Potassium nitrate oral capsules $8 \mathrm{mmol}$

Intravenous infusion of sodium nitrite for $48 \mathrm{~h}$ from $4.2 \mu \mathrm{g} / \mathrm{kg} / \mathrm{h}$ to $533.8 \mu \mathrm{g} / \mathrm{kg} / \mathrm{h}$

Supplementation with potassium nitrate (capsules -4 to $24 \mathrm{mmol}$ ) or beetroot juice $250 \mathrm{ml}$ containing $5.5 \mathrm{mmol}$ nitrate

Dietary nitrate via beetroot juice $500 \mathrm{ml}$ (5.2 mmol nitrate)/day for 15 days

Dietary nitrate provided via Japanese traditional diet. Estimated nitrate intake $18.8 \mathrm{mg} / \mathrm{kg} /$ day

Sodium nitrite infusion into brachial artery $1 \mu \mathrm{mol} / \mathrm{min}$ for $30 \mathrm{~min}$

Intravenous infusion of sodium nitrite (brachial artery: $0.4-40 \mu \mathrm{mol} / \mathrm{min}$ )
Results Reference

Hypertensive patients showed a dose-

(Ghosh et al., 2013)

dependent effect of plasma nitrite with decrease in BP and was associated with increased XOR activity. The study showed that this effect was associated with increase in erythrocytic XOR expression but not in the blood vessel wall FBF increased markedly in CHF patients when compared to normal subjects. Unstressed forearm venous volume increased in both CHF and normal subjects, with $\mathrm{CHF}$ being hyporesponsive when compared to healthy subjects. CHF patients showed accelerated transvascular clearance of nitrite suggesting increased conversion to NO in these subjects Beetroot bread increased vasodilatation and decreased DBP

Inorganic nitrate supplementation had no effect on endothelial function despite increases in plasma nitrite levels. However, inorganic nitrate decreased SBP and aortic pulse wave velocity, but had no effect on DBP

Nitrite induced a decrease in MAP in healthy subjects. The maximum tolerated dose of nitrite was $267 \mu \mathrm{g} / \mathrm{kg} / \mathrm{h}$ with toxicity occurring at $446 \mu \mathrm{g} / \mathrm{kg} / \mathrm{h}$. Concluded that nitrite was safe to infuse for a prolonged period given the correct dose Nitrate supplementation or beetroot juice caused an increase in plasma nitrite and cGMP levels, and was associated with decreased BP in healthy subjects. Sex difference in sensitivity to nitrate was dependent on baseline plasma nitrite concentration and BP, whereby males had lower baseline nitrite levels and higher BP than females. Following nitrate supplementation males had significantly greater reduction in BP than the females, thus suggesting differences in nitrate conversion to nitrite between the two sexes Nitrate supplementation elevated plasma nitrite concentrations both short term (2.5 h) and long term (15 days). Increased plasma nitrite concentration was associated with decreased BP and the $\mathrm{O}_{2}$ cost of moderate intensity exercise

Consumption of Japanese traditional diet over a period of ten days increased plasma and salivary levels of both nitrate and nitrite. Japanese traditional diet was associated with a decrease in BP in healthy normotensive subjects

During hypoxia sodium nitrite increased

FBF and reduced pulmonary arterial pressure. No effects were observed during normoxia

Nitrite infusion increased plasma nitrite in a dose-dependent manner which was associated with an increase in FBF in both healthy controls (Cosby et al., 2003) and patients with sickle cell disease.

However, the response/sensitivity to nitrite was reduced in patients with sickle cell disease
(Maher et al., 2013)

(Hobbs et al., 2013)

(Bahra et al., 2012)

(Pluta et al., 2011)

(Kapil et al., 2010a)

(Vanhatalo et al., 2010)

(Sobko et al., 2010)

(Ingram et al., 2010)

(Mack et al., 2008) 
Table 2 (continued)

\begin{tabular}{|c|c|c|c|c|}
\hline Condition/model & Nitrite reductase & $\begin{array}{l}\text { Dose/route/timing administration } \\
\text { of nitrite }\end{array}$ & Results & Reference \\
\hline $\begin{array}{l}\text { Healthy subjects. Assessed } \\
\text { effect of dietary nitrate on BP }\end{array}$ & & $\begin{array}{l}\text { Dietary nitrate via beetroot } \\
\text { juice } 500 \mathrm{ml} \\
\text { (nitrate content } \approx 45.0 \mathrm{mmol} / \mathrm{l} \text { ) }\end{array}$ & $\begin{array}{l}\text { Beetroot juice caused an increase in } \\
\text { plasma nitrite levels and decrease in BP. } \\
\text { This effect was abolished by the } \\
\text { interruption of enterosalivary reduction } \\
\text { of nitrate to nitrite via spitting. The study } \\
\text { demonstrated that the conversion of } \\
\text { nitrate to nitrite is essential for } \\
\text { vasoactivity }\end{array}$ & (Webb et al., 2008b) \\
\hline $\begin{array}{l}\text { Assessment of FBF and forearm } \\
\text { venous volume during } \\
\text { normoxia and hypoxia in } \\
\text { healthy subjects }\end{array}$ & - & $\begin{array}{l}\text { Brachial artery infusion of } \\
\text { sodium nitrite } \\
\text { ( } 40 \mathrm{nmol} / \mathrm{min} \text { to } 7.84 \mu \mathrm{mol} / \mathrm{min} \text { ) }\end{array}$ & $\begin{array}{l}\text { Nitrite was a potent venodilator during } \\
\text { normoxic and hypoxic conditions. While } \\
\text { nitrite had a modest vasodilatory effect } \\
\text { in the resistance vessels during } \\
\text { normoxia, the effect was potent during } \\
\text { hypoxia }\end{array}$ & (Maher et al., 2008) \\
\hline $\begin{array}{l}\text { Assessed the physiological and } \\
\text { pharmacological effects of } \\
\text { sodium nitrite on vasodilatory } \\
\text { responses }\end{array}$ & XOR and deoxyHb & $\begin{array}{l}0,7,14,28,55 \text { and } 110 \mu \mathrm{g} / \mathrm{kg} / \mathrm{min} \\
5 \mathrm{~min} \text { each dose }\end{array}$ & $\begin{array}{l}\text { Sodium nitrite was a potent vasodilator } \\
\text { at near-physiological concentrations. Ni- } \\
\text { trite was reduced to NO by intravascular } \\
\text { reactions with deoxyHb. In contrast, XOR } \\
\text { inhibition did not attenuate the nitrite- } \\
\text { induced vasodilatation }\end{array}$ & (Dejam et al., 2007) \\
\hline $\mathrm{BP}$ in healthy subjects & - & $\begin{array}{l}3 \text { day dietary supplementation } \\
\text { with sodium nitrate }(0.1 \mathrm{mmol} / \mathrm{kg} / \\
\text { day) }\end{array}$ & $\begin{array}{l}\text { Short term dietary nitrate } \\
\text { supplementation increased plasma } \\
\text { nitrite levels and reduced DBP and MAP, } \\
\text { but did not affect SBP in healthy subjects }\end{array}$ & (Larsen et al., 2006) \\
\hline $\begin{array}{l}\text { Subjects with endothelial } \\
\text { dysfunction compared to } \\
\text { healthy subjects }\end{array}$ & - & Endogenous plasma nitrite & $\begin{array}{l}\text { Subjects with endothelial dysfunction } \\
\text { displayed lower levels of plasma nitrite } \\
\text { and lower FMD levels than healthy sub- } \\
\text { jects }\end{array}$ & (Kleinbongard et al., 2003) \\
\hline $\begin{array}{l}\text { Assessed the vasodilatory } \\
\text { properties and bioactivation of } \\
\text { nitrite in forearm (via FBF) } \\
\text { before and during exercise }\end{array}$ & DeoxyHb & $\begin{array}{l}\text { Infusion of sodium nitrite } 0.36 \text { and } \\
36 \mu \mathrm{mol} / \mathrm{min} \text { before and during } \\
\text { exercise }\end{array}$ & $\begin{array}{l}\text { Sodium nitrite induced vasodilatation in } \\
\text { humans and was associated with } \\
\text { reduction of nitrite to NO by deoxyHb } \\
\text { during hypoxic conditions }\end{array}$ & (Cosby et al., 2003) \\
\hline $\begin{array}{l}\text { Assessed whether changes in } \\
\text { NOS concentrations are reliable } \\
\text { marker for NO production and } \\
\text { whether physiological concen- } \\
\text { tration of nitrite is vasoactive }\end{array}$ & eNOS & $\begin{array}{l}\text { Intra-arterial infusion of sodium } \\
\text { nitrite } 0.01-36 \mu \mathrm{mol} / \mathrm{min}\end{array}$ & $\begin{array}{l}\text { eNOS stimulation with ACh dose- } \\
\text { dependently increased venous nitrite } \\
\text { levels and this effect was associated by } \\
\text { an increase in FBF. Intra-arterial infusion } \\
\text { of nitrite had no effect on FBF }\end{array}$ & (Lauer et al., 2001) \\
\hline
\end{tabular}

human studies as a convenient source of nitrate, not least because it is classified as 'food', simplifying the administrative effort required to carry out human studies in the UK and other countries. Beetroot juice consumption in healthy volunteers has been shown to be associated with an increase in the levels of plasma nitrate (by 16 fold) and nitrite (by 2 fold) (Webb et al., 2008b). Cermak and colleagues reported a similar trend with regard to plasma nitrite levels in trained male cyclists. Control subjects who consumed $140 \mathrm{ml}$ nitrate-depleted beetroot juice had plasma nitrite levels of $271 \mathrm{nmol} / \mathrm{l}$, whereas subjects consuming the same volume of beetroot juice (containing $8.7 \mathrm{mmol}$ nitrate) showed a two-fold higher plasma nitrite level of $532 \mathrm{nmol} / \mathrm{l}$ (Cermak et al., 2012). It has also recently been demonstrated that nitrite/nitrate handling in humans shows sexual dimorphism: increases in plasma nitrate and nitrite levels as well as inhibition of platelet function after consumption of beetroot juice revealed a clear gender difference (Velmurugan et al., 2013).

The consumption of dietary nitrate from beetroot juice in healthy volunteers has been shown by Wylie and colleagues to increase plasma nitrate and nitrite levels in a dose-dependent manner (Wylie et al., 2013). Volunteers were given beetroot juice containing $4.2,8.4$ or $16.8 \mathrm{mmol}$ nitrate; the level of circulating nitrate peaked at values of $160 \pm 43 \mu \mathrm{mol} / \mathrm{l}, 269 \pm 92 \mu \mathrm{mol} / \mathrm{l}$ and $581 \pm 209 \mu \mathrm{mol} / \mathrm{l}$, respectively (all $P<0.05$ ). These corresponded with increases in plasma nitrite to $220 \pm 104 \mathrm{nmol} / \mathrm{l}, 374 \pm 173 \mathrm{nmol} / \mathrm{l}$ and $653 \pm 356 \mathrm{nmol} / \mathrm{l}$ (all $P<0.05$ ) respective to increasing dose (Wylie et al., 2013). Furthermore, Vanhatalo et al. demonstrated that continued beetroot juice consumption over a period of 15 days resulted in sustained elevation of plasma nitrite levels (Vanhatalo et al., 2010). The authors found that consumption of beetroot juice containing $5.2 \mathrm{mmol}$ nitrate/day significantly elevated plasma nitrite levels by $35 \% 2.5 \mathrm{~h}$ after ingestion, $25 \%$ at 5 days and $46 \%$ at 15 days, as discussed further in Section 6.1.

\section{Effects of nitrite and nitrate on cardiovascular function}

\subsection{Effect of dietary nitrates}

As discussed in Section 5.2 and depicted in Table 2, several research groups have demonstrated that ingestion of dietary nitrate (beetroot juice) in healthy subjects results in increased plasma nitrite concentration via bioconversion in vivo (Webb et al., 2008b; Kapil et al., 2010a; Cermak et al., 2012; Velmurugan et al., 2013; Wylie et al., 2013) and substantial research efforts have focused to investigate the role of this bioactive nitrite on cardiovascular function (Webb et al., 2008b; Vanhatalo et al., 2010; Lansley et al., 2011; Bondonno et al., 2012; Wylie et al., 2013). For instance, Webb and colleagues reported a substantial reduction in systolic blood pressure (SBP) of $10.4 \mathrm{~mm} \mathrm{Hg} 3 \mathrm{~h}$ after ingestion of beetroot juice, and this effect inversely correlated with peak increases in plasma nitrite levels (Webb et al., 2008b). In order to ascertain that nitrite was indeed the carrier of bioactivity that accounts for the BP change, a complementary spitting study was conducted. The results clearly demonstrated that spitting caused interruption of the enterosalivary recirculation of dietary nitrate in as much as it abolished both the rise in plasma nitrite and the decrease in BP (Webb et al., 2008b).

The consumption of nitrate rich spinach has been shown to decrease SBP, by $2.7 \mathrm{~mm} \mathrm{Hg}$, and increase flow mediated dilatation (FMD) of the brachial artery, by $0.5 \%$, in healthy volunteers (Bondonno et al., 2012). The response of healthy volunteers to dietary nitrate via beetroot juice 
consumption has been demonstrated to show a dose-response relationship between nitrate load and BP. Ingestion of beetroot juice decreased SBP and mean arterial pressure in relation to nitrate dose (Wylie et al., 2013). Decreases in diastolic blood pressure (DBP) were only found with the higher doses of nitrate in this study. These changes in BP correlated with changes in plasma nitrate and nitrite. The same study also demonstrated that dietary nitrate can reduce steady-state oxygen uptake during moderate intensity exercise and increases time to task failure (Wylie et al., 2013). In agreement with the lack of tolerance development to the vasodilator effects of nitrite alluded to earlier, Vanhatalo and co workers have shown that elevated plasma nitrite levels during subchronic consumption of beetroot juice over a period of 2 weeks is associated with a sustained decrease in SBP and DBP and reduced $\mathrm{O}_{2}$ cost of submaximal exercise (Vanhatalo et al., 2010). Similarly, Lansley and colleagues showed that elevated plasma nitrate and nitrite in healthy competitive male cyclists improved performance in time trial cycling without alteration of $\mathrm{VO}_{2}$ max by improving exercise efficiency (Lansley et al., 2011). In contrast to these results in fit but untrained or moderately trained athletes, dietary nitrate supplementation has not been demonstrated to have beneficial effects on exercise performance or endurance in elite athletes (Peacock et al., 2012; Christensen et al., 2013).

Overall, the results from these studies suggest that oral nitrate administration, particularly via beetroot juice, increases plasma nitrite levels and produces a moderate vasodilator response in healthy volunteers. The effects of dietary nitrate have also been investigated in the setting of chronic environmental hypoxia and under pathophysiological conditions (Ghosh et al., 2013; Martin et al., 2013). A double-blind placebo-controlled study of the effects of beetroot juice on various bodily functions was carried out in 28 healthy human volunteers, first at sea level and then during 5 days at high altitude (4559 m) (Martin et al., 2013). The purpose of this study was to investigate whether the beneficial effects of nitrate on mitochondrial efficiency observed in some of the studies described above are maintained or might even be enhanced under conditions of reduced oxygen availability; if the latter was true this could be of benefit for critically ill patients suffering from hypoxemia. Publication of results from this study is eagerly awaited.

In another investigation in patients with grade 1 hypertension it has been shown that the consumption of beetroot juice can elevate plasma nitrite levels by 1.5 fold, with the increase being associated with a decrease in both SBP and DBP (Ghosh et al., 2013). Grade 1 hypertensives were classed as those with SBP between 140 and $159 \mathrm{~mm}$ Hg or DBP 90 and $99 \mathrm{~mm} \mathrm{Hg}$. Dietary nitrate was consumed by drinking $250 \mathrm{ml}$ of beetroot juice with nitrate concentration of $13.2 \mathrm{mmol} / \mathrm{l}$. The SBP in these patients was shown to decrease, with peak mean fall in pressure occurring between 3 and $6 \mathrm{~h}$ after consumption of beetroot juice at $11.2 \mathrm{~mm} \mathrm{Hg}$ compared to $0.7 \mathrm{~mm} \mathrm{Hg}$ in controls (Ghosh et al., 2013). DBP was also reduced in hypertensive patients who consumed beetroot juice, with a peak mean fall in pressure of $9.6 \mathrm{~mm} \mathrm{Hg}$. Similar to healthy volunteers, in hypertensive patients the decrease in SBP was inversely correlated with plasma nitrite but not nitrate levels. It is interesting that compared to healthy volunteers, a lower dose of dietary nitrate is required to produce a comparable drop in SBP and DBP in hypertensive patients, perhaps because of these patients' higher BP at baseline (Ghosh et al., 2013).

Another recent investigation is of interest in the context of discussions about the effects of nitrite and nitrate on BP. In this study, the skin of 24 healthy human volunteers was exposed for 20 min to ultraviolet A (UVA) radiation from tanning lamps. During and up to half an hour after UVA exposure DBP was significantly lowered by $\sim 5 \mathrm{~mm} \mathrm{Hg}$, and these hemodynamic changes were associated with opposite changes in circulating nitrate and nitrite concentrations (Liu et al., 2014). These light-induced BP changes were independent of changes in vitamin $\mathrm{D}$ levels and suggested translocation of NO bioactivity from a preformed storage pool in the skin to the circulation, resulting in an elevation of plasma nitrite at the expense of nitrate. Surprisingly, an acute 10-fold elevation of circulating nitrate levels (from basal concentrations of $10.7 \mu \mathrm{mol} / \mathrm{l}$ on a low nitrate diet to $108 \mu \mathrm{mol} / \mathrm{L} 1 \mathrm{~h}$ after acute oral ingestion of sodium nitrate) did not alter the hemodynamic effects of UVA light. Thus, in addition to the bioactivation of nitrate to nitrite via oral commensal bacteria, another endogenous pool of nitrate (or a closely related NO species that can give rise to nitrite) appears to exist in human skin that may contribute to BP regulation in response to exposure of the body to UVA/sunlight.

These studies built on earlier investigations on the effects of light on vascular tone of isolated rabbit aortic strips in organ baths (Furchgott et al., 1961), a phenomenon known as 'photorelaxation'. In those studies, addition of sodium nitrite to the organ bath potentiated lightinduced vasorelaxation in an endothelium-independent manner (Matsunaga \& Furchgott, 1989). This effect of nitrite was potentiated by the presence of superoxide dismutase or other $\mathrm{O}_{2}^{-}$scavengers (Matsunaga \& Furchgott, 1989, 1991), demonstrating the importance of the balance between $\mathrm{NO}$ and $\mathrm{O}_{2}^{-}$. Later studies in rat aortic rings showed that the release of NO from vascular storage forms comprising S-nitrosothiols and nitrite account for the phenomenon of photorelaxation (Rodriguez et al., 2003).

\subsection{Nitrite-mediated vasodilatation in physiological and pathophysiological conditions}

\subsubsection{Animal studies}

The use of nitrite as a BP lowering agent dates back to the beginning of the last century (Butler \& Feelisch, 2008). In 1953, the ability of nitrite to act as a vasodilator was first demonstrated by Furchgott and Bhadrakom who showed that administration of sodium nitrite to precontracted rabbit aortic strips in vitro induced vasorelaxation (Furchgott \& Bhadrakom, 1953). In subsequent studies $200 \mu \mathrm{mol} / \mathrm{l} \mathrm{ni-}$ trite was shown to relax rat aorta in vitro under normoxic conditions, with a reduction to $40 \mu \mathrm{mol} / \mathrm{l}$ required under hypoxia (Modin et al., 2001). While in a canine model under normoxic conditions aortic relaxation has been shown to occur with administration of nitrite at levels between 100 and $1000 \mu \mathrm{mol} / \mathrm{l}$ (Arai, 2006). In more recent work, high micromolar to millimolar pharmacological concentrations of exogenously administered nitrite have been demonstrated to relax preconstricted isolated blood vessels (Maher et al., 2008; Ormerod et al., 2011). Thus, when studied using isolated vascular preparations nitrite is far less potent vasodilator than NO itself. In very early work by Reichert and Mitchell (1880), potassium nitrite was found to exert a dose-dependent effect on pulse (at the time these experiments were conducted routine BP measurement was not yet part of clinical practice and only possible using somewhat cumbersome invasive methods (Booth, 1977); thus, pulse rate was used as a proxy for systemic effects on the circulation). In man, 2 grains of potassium nitrite showed little effect on pulse ( 1 grain is a unit of mass equal to $65 \mathrm{mg}$; 2 grains translate into a dose of $\sim 2 \mathrm{mg} / \mathrm{kg}$ ). When the dose was increased to 6 grains, the pulse (measured 40 min after nitrite administration) was increased by $\sim 30$ beats per minute; this was associated with throbbing vessels and warmth to the face. Ten grains of potassium nitrite increased pulse to an even greater extent within $25 \mathrm{~min}$, concurrent with flushed face and hands and a throbbing headache. These observations are consistent with systemic and peripheral vasodilatation. The same authors also reported the effects of potassium nitrite on arterial BP in animals. In experimental rabbits, cats and dogs, large doses of potassium nitrite $(0.2$ $\mathrm{g}$ in rabbits and cats and $0.5-1.0 \mathrm{~g}$ in dogs) caused an immediate and continual decrease in BP to zero. However, a smaller dose $(0.08 \mathrm{~g})$ increased BP within $30 \mathrm{~s}$ after administration, which was followed by a decline in pressure; further administration of nitrite caused a similar pattern of transient increase followed by a large, sustained fall in blood pressure (Reichert \& Mitchell, 1880). A similar dose-dependent effect of nitrite on BP has been reported more recently by Feelisch and colleagues (Bryan et al., 2005). Intraperitoneally administered low doses $(0.1 \mathrm{mg} / \mathrm{kg})$ of sodium nitrite in rats caused a small, non- 
significant increase in mean arterial blood pressure (MAP) while higher doses ( 1.0 and $10 \mathrm{mg} / \mathrm{kg}$ ) decreased BP by a maximum of $5 \%$ and $27 \%$ of controls, respectively. Since no direct vasoconstrictor effects to nitrite have been observed in vitro, these studies suggest that in vivo nitrite has a dual effect on the vasculature, acting as a vasodilator at higher doses while eliciting a transient pressor effect at lower to intermediate doses; the latter may be secondary to functional interaction with other vasoactive factors.

In an in vivo study in Wistar rats, it has been demonstrated that administration of either infused sodium nitrite, or potassium nitrite supplemented in the drinking water is associated with a decrease in MAP in both anaesthetized and freely moving rats (Vleeming et al., 1997). In a mouse model of ischemic (hypoxic) hind-limb, hypertensive mice showed a significantly decreased blood flow compared to sham operated mice, and blood flow could be recovered in both hypertensive and normotensive mice when treated with sodium nitrite compared to non-treated mice. Inhibition of XOR prevented this recovery, suggesting a role for XOR-mediated reduction of nitrite to NO in blood flow under these conditions, as suggested in in vitro studies (Li et al., 2003; Amin et al., 2012). Hypertensive mice also demonstrated a decrease in cGMP levels compared to control mice in the hind limb (Amin et al., 2012). However, treatment with sodium nitrite was found to significantly enhance cGMP levels; thus in this study, it was suggested that sodium nitrite could be used as a therapy for full recovery of blood flow. Table 1 summarises studies to date investigating the role of nitrite on vasodilatation and BP in animal models.

\subsubsection{Translational studies in man}

The vasodilatory effects of nitrite infusion were later translated to healthy human volunteers. In 2003, Cosby and colleagues showed that sodium nitrite vasodilates the forearm vasculature when infused into the brachial artery (Cosby et al., 2003). Initially, a high dose of $36 \mu \mathrm{mol} / \mathrm{min}(2.4 \mathrm{mg} / \mathrm{min})$, resulting in an approximate intravascular nitrite concentration of $200 \mu \mathrm{mol} / \mathrm{l}$, was tested and found to significantly increase FBF both with and without NOS inhibition by $N$-methylarginine ( $n=10, P<0.01)$. FBF increased further on forearm exercise during continued nitrite infusion, despite relative reduction in nitrite concentration due to increased blood flow. Cosby and colleagues went on to test a "near-physiological" dose of $400 \mathrm{nmol} / \mathrm{min}(27.6 \mu \mathrm{g} / \mathrm{min})$, which significantly increased FBF from $3.5 \pm 0.2$ to $4.5 \pm 0.3 \mathrm{ml} / \mathrm{min} / 100 \mathrm{ml}$ tissue ( $n=10, P<0.006)$ at rest, and to a greater extent on exercise (Cosby et al., 2003). The authors concluded that basal levels of nitrite are capable of influencing resting vascular tone and subserving hypoxic vasodilatation. In subsequent studies, the same group extended their previous observations with systemic nitrite. A lower dose of sodium nitrite, resulting in a plasma concentration of just $350 \mathrm{nmol} / \mathrm{l}$, was found to cause a significant drop in BP in healthy volunteers. In addition, the authors showed a dose-dependent increase in sodium nitrite infusion ( 0 to $110 \mu \mathrm{g} / \mathrm{kg} / \mathrm{min}$ ) increased FBF from 2.8 to $12.3 \mathrm{ml} / \mathrm{min} / 100 \mathrm{ml}$ tissue (Dejam et al., 2007).

In support of an enhanced role of nitrite during hypoxia, the effects of sodium nitrite infusion during normoxia and hypoxia, respectively in healthy volunteers were investigated by our group (Maher et al., 2008). Sodium nitrite was infused into the forearm brachial artery at doses from $40 \mathrm{nmol} / \mathrm{min}$ to $7.84 \mu \mathrm{mol} / \mathrm{min}$ (Maher et al., 2008). Under normoxic conditions, large decreases in forearm venous tone were found at doses between $784 \mathrm{nmol} / \mathrm{min}$ and $7.84 \mu \mathrm{mol} / \mathrm{min}$, with peak venodilatation of $35.8 \%( \pm 7.5 \% P<0.005)$ occurring at the highest infused dose of $7.84 \mu \mathrm{mol} / \mathrm{min}$. The forearm blood flow ratio (FBF-R: FBF corrected for control arm) was increased during the two highest doses of nitrite infusion at $3.14 \mu \mathrm{mol} / \mathrm{min}$ and $7.84 \mu \mathrm{mol} / \mathrm{min}$, increasing from a baseline of 1.0 to 1.8 and 1.6 respectively (Maher et al., 2008). Under hypoxic conditions, FBF-R was enhanced following infusion of $7.84 \mu \mathrm{mol} / \mathrm{min}$ and FBF-R significantly increased compared to the same dose under normoxic conditions $(P<0.05)$. We concluded that under normoxic conditions, nitrite was a potent vasodilator of capacitance vessels but only a modest dilator of resistance vessels (compared with other vasodilating agents), while under hypoxic conditions administration of exogenous sodium nitrite has a substantial relaxation effect on resistance vessels. This may be due to the relatively low $\mathrm{PO}_{2}$ in the capacitance bed compared to resistance vessels under physiological conditions; thus the effect of nitrite on capacitance vessels will be more pronounced in normoxia, whereas in hypoxia nitrite demonstrates a greater effect on the resistance vessels due to the decrease in $\mathrm{PO}_{2}$ approaching levels (previously seen but not markedly enhanced) in the capacitance vasculature. This study thus demonstrated that oxygen tension plays an essential role in determining the vasodilatory response to nitrite (Maher et al., 2008), although it does not exclude the involvement of other contributing factors. Table 2 summarises the recent studies that have investigated the efficacy and potential mechanisms of nitrite-mediated vasorelaxation and BP reduction in healthy and pathophysiological conditions, such as patients with hypertension or heart failure.

There are noticeable discrepancies between studies regarding to the dose of nitrite and increased blood flow in normoxia (Lauer et al., 2001; Cosby et al., 2003; Maher et al., 2008). It has been proposed that in normoxia, both acetylcholine (Larrousse et al., 2006) and bradykinin (Wotherspoon et al., 2005) are more effective vasodilators, inducing increase in blood flow by three to four fold, but that in hypoxia it appears that nitrite plays a dominant role. This would suggest that different pathways exist to confer vasodilatation during normoxia and hypoxia and the differing conversion of nitrite to NO under varying oxygen tensions is thus believed to be an important feature integral to hypoxic signalling.

The results on nitrite on human FBF under normoxic conditions (Cosby et al., 2003) are in stark contrast to earlier findings by Lauer et al. (Lauer et al., 2001), claiming that nitrite had no direct vasodilator effect when intra-arterially infused, for one minute, at a rate identical to that used in the Cosby study. An explanation for this discrepancy is discussed in Section 7 (mechanisms of nitrite-mediated vasodilatation).

With regard to nitrite administration in pathophysiological conditions, a study comparing the intraarterial effects of nitrite administration in healthy volunteers with congestive heart failure (CHF) patients highlighted differing effects of nitrite administration between the two groups (Maher et al., 2013), with evidence of hyperresponsiveness in forearm resistance vessels in the latter (Maher et al., 2013). In contrast there was reduced venodilation in the heart failure patients, however at any given nitrite infusion dose the venous levels of plasma nitrite were lower in the heart failure patients vs controls indicating increased clearance across the forearm vascular bed and possibly explaining the apparent venous hyporesponsiveness (Maher et al., 2013). The results from these studies in patients with CVD highlights complications which may arise when translating results from both animal models and healthy human models into clinical settings, and more research in the presence of particular disease states may be required to fully understand how nitrite, and indeed other forms of therapy, can be applied for maximum patient benefit and improved clinical outcome.

\subsection{Role of nitrite at different oxygen tensions}

Studies have shown that the level of nitrite in plasma appears with an apparent arteriovenous gradient, showing greater vasodilatation activity in the capacitance vessels under normoxic conditions and in the resistance vessels under hypoxic conditions (Maher et al., 2008, 2013). This effect has also been observed in studies of human FBF, most notably during exercise (Gladwin et al., 2000; Cosby et al., 2003). It has been suggested that this gradient may be due to consumption of nitrite and NO during transit along the vascular tree (Gladwin et al., 2000; Cosby et al., 2003); the nitrite reductase activity of deoxyhemoglobin (deoxyHb) in particular is suggested to play a role in nitrite-NO formation as described below. 
One molecule which has garnered more attention than any other in this area is hemoglobin ( $\mathrm{Hb})$. Oxyhemoglobin (oxyHb) and deoxyHb are known as potent NO scavengers (Joshi et al., 2002; Isbell et al., 2007), and have been shown to regulate the effects of NO (Griffith et al., 1984). However, only oxyHb chemically reacts with NO to form nitrate, deoxyHb binds it to form nitrosylHb. The balance between the different states of oxygen saturation in $\mathrm{Hb}$ has been suggested to contribute to the gradient effect between arterial and venous systems, with deoxygenation of the heme moiety suggested to express reductase activity with maximal efficiency around the p50, i.e. the oxygen partial pressure at which $50 \%$ of the hemoglobin is oxygenated (Huang et al., 2005; Crawford et al., 2006; Feelisch et al., 2008; Gladwin \& Kim-Shapiro, 2008). It has been suggested that $\mathrm{Hb}$ acts as a nitrite reductase in the blood, with red blood cells (RBC) representing the principle source of $\mathrm{Hb}$ and a carrier of nitrite (Dejam et al., 2005). Hb can interact with blood nitrite via a redox process determined through both the heme redox potential and oxygen saturation of $\mathrm{Hb}$ (Shiva et al., 2011). A particular balance of oxyHb to deoxyHb is required for optimal reduction of nitrite to NO, peaking around the p50 value. The NO produced may then interact with mitochondrial cytochrome $c$ oxidase which contains a binuclear centre to which oxygen ordinarily binds in the mitochondrial respiratory chain. However, upon cytochrome $c$ oxidase-NO binding, oxygen binding becomes inhibited, and mitochondrial respiration is reduced (Shiva et al., 2011). During hypoxia, NO-mediated inhibition of mitochondrial respiration is enhanced. This process may aid the extension of oxygen gradients in tissues ensuring oxygen delivery to a greater tissue area, regulating mitochondrial ROS generation and the action of Hypoxia Inducible Factor $1-\alpha$ (Hagen et al., 2003). Physiologically, the vasodilatory action of $\mathrm{Hb}$ reduction of nitrite to NO is suggested to mediate the cGMP-dependent pathway of vasodilatation in hypoxia (Cosby et al., 2003; Huang et al., 2005; Jeffers et al., 2005; Crawford et al., 2006).

The effect of oxygen tension on nitrite metabolism has also been investigated in animal experimental models. RBC homogenates showed the expected behaviour in as much as NO production from nitrite was found to be maximal around the p50 value of $\mathrm{Hb}$ (Feelisch et al., 2008). In contrast, in rat tissue homogenates the in vitro reduction of nitrite to NO was shown to be limited under normoxic conditions, while nitrite to NO conversion progressively increased at lower oxygen concentrations in all organs, including vascular tissue (Feelisch et al., 2008). This metabolic activity was associated with an increase in the formation of nitrosated and nitrosylated products in vivo. The formation of NO from nitrite was found to be largely enzymatic in nature as it was sensitive to heat inactivation and blockage of thiol groups (Feelisch et al., 2008), supporting earlier studies implicating heme and thiolcontaining reductases in this process (Bryan et al., 2005). Data from a more recent in vivo study carried out in rats suggest that acute hypoxic vasodilatation is largely mediated by NO metabolites rather than by free NO from Hb-mediated nitrite reduction (Umbrello et al., 2014).

The step-wise reduction of nitrate to nitrite and nitrite to NO has been demonstrated under anoxic conditions in vitro with a role for nitrate/nitrite reductase xanthine oxidase (XO) (Li et al., 2003). The authors of this study also found that nitrite and NO production was $\mathrm{pH}$-dependent with maximum observable NO production at $\mathrm{pH} 5.0$, suggesting that XO reduces nitrate to nitrite and NO under acidic conditions, as associated with CVD (Li et al., 2003).

\section{Mechanisms of nitrite-mediated vasodilatation}

Much of our current understanding about nitrite's mode of action as a vasodilator is based on animal experimental work and observed associations of changes in circulating plasma concentrations and blood flow and/or pressure at pharmacological doses; other pieces of information are derived from in vitro studies with isolated proteins or cultured cells. Considerably less information is available on the mechanism of vasodilatation by nitrite in human tissue and the role, if any, of endogenous nitrite for human physiology. The fact that nitrite can relax isolated segments of precontracted vascular tissue in organ baths does not necessarily mean that it is involved in the regulation of BP. Part of the paucity of mechanistic information is due to the fact that monitoring the rather low concentrations of endogenous nitrite requires specific analytical equipment such as HPLC or gas phase chemiluminescence, which is not available in every laboratory; another reason is that our current understanding of basic processes including nitrite/nitrate uptake, processing and excretion at the cellular and whole organism level is incomplete. Moreover, while biochemically interesting in principle some in vitro findings obtained with high nitrite concentrations under complete anoxia are likely to be of limited relevance to physiology. The lack of pharmacological tools such as specific 'nitrite scavengers' is also a limiting factor. The extrapolation of animal experimental data to human physiology requires particular care - not everything that looks promising in the animal experimental setting is ultimately going to work in humans.

It is important to acknowledge that no 'nitrite receptor' has yet been described; thus, there is no mechanistic basis for a direct coupling of a nitrite recognition site to a down-stream signalling event in smooth muscle to trigger vasodilatation. Therefore, the vasodilator effects of nitrite are not, at least at present, known to be a consequence of interaction with a specific receptor in vascular tissue; with no 'nitrite receptor' as target, there is likely no simple concentration-response relationship for its biological effect either. Although it cannot be excluded at present that nitrite may affect processes coupled to the transport of other anions in the vasculature (a process that could conceivably affect vascular tone), all evidence available to this date suggests that nitrite has to be metabolized to NO, or an NO-like species, in order to exert a biological effect. This process appears to require the presence of a sulfhydryl group and a heme moiety (Bryan et al., 2005). There is no agreement in the literature as to whether nitrite is metabolized intracellularly or bioactivated in the extracellular space. Nitrite may require prior entry to the tissue first before it can act as a vasodilator. In this case, the plas$\mathrm{ma} /$ tissue concentration gradient would seem to be important, but transport may well be via a carrier-facilitated uptake, with competition by other anions - little is known about any of this. Once inside the vascular tissue, nitrite may interact with one of the enzymes described below to become reduced to $\mathrm{NO}$ (or $\mathrm{N}_{2} \mathrm{O}_{3}$ ) and/or become biotransformed to nitroso and/or nitrosyl species before being able to interact with $\mathrm{SGC}$ to produce cGMP. However, nitrite transport into cells may not be required in all cases as it has recently been shown that nitrite reduction can also occur through red blood cell (or endothelial cell) nitrite reductases such as XOR (Ghosh et al., 2013) to mediate a vasodilatory response.

A surprisingly large number of different proteins have been identified that can reduce nitrite to NO in vitro, and detailed recent reviews on this topic are available (van Faassen et al., 2009; Kapil et al., 2010b; Lundberg \& Weitzberg, 2010; Kim-Shapiro \& Gladwin, 2013). However, there is neither agreement in the literature as to which of these potential nitrite bioactivation processes are the most relevant for vasodilatation (or any other biological process), nor do we understand the reason for this particularly high degree of redundancy. In principle, the processes involved are chemical/non-enzymatic or enzymatic, with different $\mathrm{pH}$ optima for nitrite reduction depending on the nature of the proteins involved. Many of the enzymatic pathways demand rather low concentrations of oxygen to reduce nitrite efficiently. In fact, oxygen appears to be a highly effective inhibitor of tissue 'nitrite reductase' activity (Feelisch et al., 2008). Thus, hypoxia does not 'stimulate' nitrite reduction, it is rather that lower levels of oxygen result in less inhibition.

The simplest chemical pathway of NO generation from nitrite involves disproportionation of the corresponding acid, $\mathrm{HNO}_{2}$. This pathway is probably not of much relevance for nitrite bioactivation in vascular tissue, unless it is rendered hypoxic for a prolonged period of time. Both $\mathrm{Hb}$ (Basu et al., 2007) and carbonic anhydrase (Aamand 
et al., 2009) have been reported to possess nitrite/nitrous acid anhydrase activity, a reaction in the course of which $\mathrm{N}_{2} \mathrm{O}_{3}$ is formed, eventually giving rise to $\mathrm{NO}$ and $\mathrm{NO}_{2}$. While the former could theoretically provide a convenient way of exporting nitrite-derived NO from RBCs under hypoxic conditions, recent animal experimental results suggest that the majority of hypoxic vasodilatation is not mediated by Hbmediated nitrite reduction (Umbrello et al., 2014). The nitrite reductase activity of carbonic anhydrase appears to be linked to the coupling of cerebral blood flow and metabolic activity in response to visual stimulation (Aamand et al., 1985, 2009).

It would perhaps be desirable to group proteins according to the mechanism involved in nitrite reduction, but this is not known for all proteins to date. Moreover, a single protein may employ several different pathways to reduce nitrite to NO; in the case of $\mathrm{Hb}$ and myoglobin $(\mathrm{Mb})$ these have been proposed to include R-state catalysis, oxidative denitrosylation (of the intermediate NO-heme product formed), and the above nitrite anhydrase reaction (Gladwin et al., 2009). Alternatively, a thiol group in $\mathrm{Hb}$ may become nitrosated during deoxygenation/ reoxygenation, by a mechanism involving NO-heme formation from nitrite, to form a nitrosothiol (SNO-Hb) which may serve as NO-carrier (Angelo et al., 2006), or that nitrite is reduced by the eNOS expressed in RBCs (Cortese-Krott et al., 2012) under some conditions. Thus, even for some of the most extensively studied proteins the precise mechanisms involved remain unclear. As a result, proteins are typically categorised according to the principle reaction they are known to catalyse (which may not always match with the mechanism involved in nitrite bioactivation, but that is another matter), or the prosthetic group they carry. According to this principle, the proteins involved in nitrite reduction can be divided into two broad groups: heme-based proteins and molybdopterin-based oxidoreductases. The two best studied examples of the former are $\mathrm{Hb}$ and $\mathrm{Mb}$, and both have been claimed to play major roles in nitrite bioactivation (Shiva et al., 2007a; Totzeck et al., 2012b; Kim-Shapiro \& Gladwin, 2013), in particular under hypoxic conditions (Crawford et al., 2006; Hendgen-Cotta et al., 2014). Less well studied members of this group include neuroglobin and cytoglobin, cytochrome $\mathrm{C}$ and cytochrome $\mathrm{C}$ reductase, cytochrome $\mathrm{P} 450$, and the endothelial NOS isoform.

The most recent member of the heme-based nitrite reductases is cystathionine beta-synthase (CBS) (Gherasim et al., 2014), a key enzyme of the transsulfuration pathway involved in homocysteine metabolism, glutathione production, and formation of hydrogen sulfide $\left(\mathrm{H}_{2} \mathrm{~S}\right)$. As with other heme-based reductases, NO-heme formation leads to autoinhibition of the enzyme, representing an interesting new facet of the $\mathrm{NO} / \mathrm{H}_{2} \mathrm{~S}$ cross-talk. Members of the molybdopterin-based oxidoreductases shown to reduce nitrite to NO involve XO (Cantu-Medellin \& Kelley, 2013), aldehyde oxidase (Li et al., 2008), and sulfite oxidase (Wang et al., 2011). Many of the above proteins have been studied in relative isolation; their importance in mediating the vasorelaxant response to nitrite has been assessed using pharmacological inhibitors (of varying specificity) and, in some cases, knockout mice. Yet most papers are limited to the investigation of one specific pathway, and reading the literature one could easily get the impression that they are all equally important, or solely responsible for the effects of nitrite under some conditions. Fig. 1 illustrates the nitrite-derived NO signalling in the vascular system.

Let us now revisit the discrepancy between the in vivo results presented by the groups of Lauer et al. and Cosby et al. mentioned in Section 6.2.2. Why did apparently identical solutions of sodium nitrite in saline produce no vasodilatation whatsoever in one case (Lauer et al., 2001) and marked increases in FBF in the other (Cosby et al., 2003) Notwithstanding minor differences in blood flow at baseline, intravascular nitrite concentrations achieved must have been of comparable magnitude. The explanation may be linked to differences in infusion times (and thus total amounts of nitrite delivered). If the same concentration of a nitrite stock solution is infused at the same rate into the vasculature then the total amount of bioactive drug (nitrite) scales with the duration of infusion. In the earlier studies by Lauer et al. infusions were limited to $1 \mathrm{~min}$ (during which time no changes in blood flow were observed, consistent with a lack of direct vasodilator effect of nitrite) whereas in the Cosby study infusions continued for as long as $5 \mathrm{~min}$.

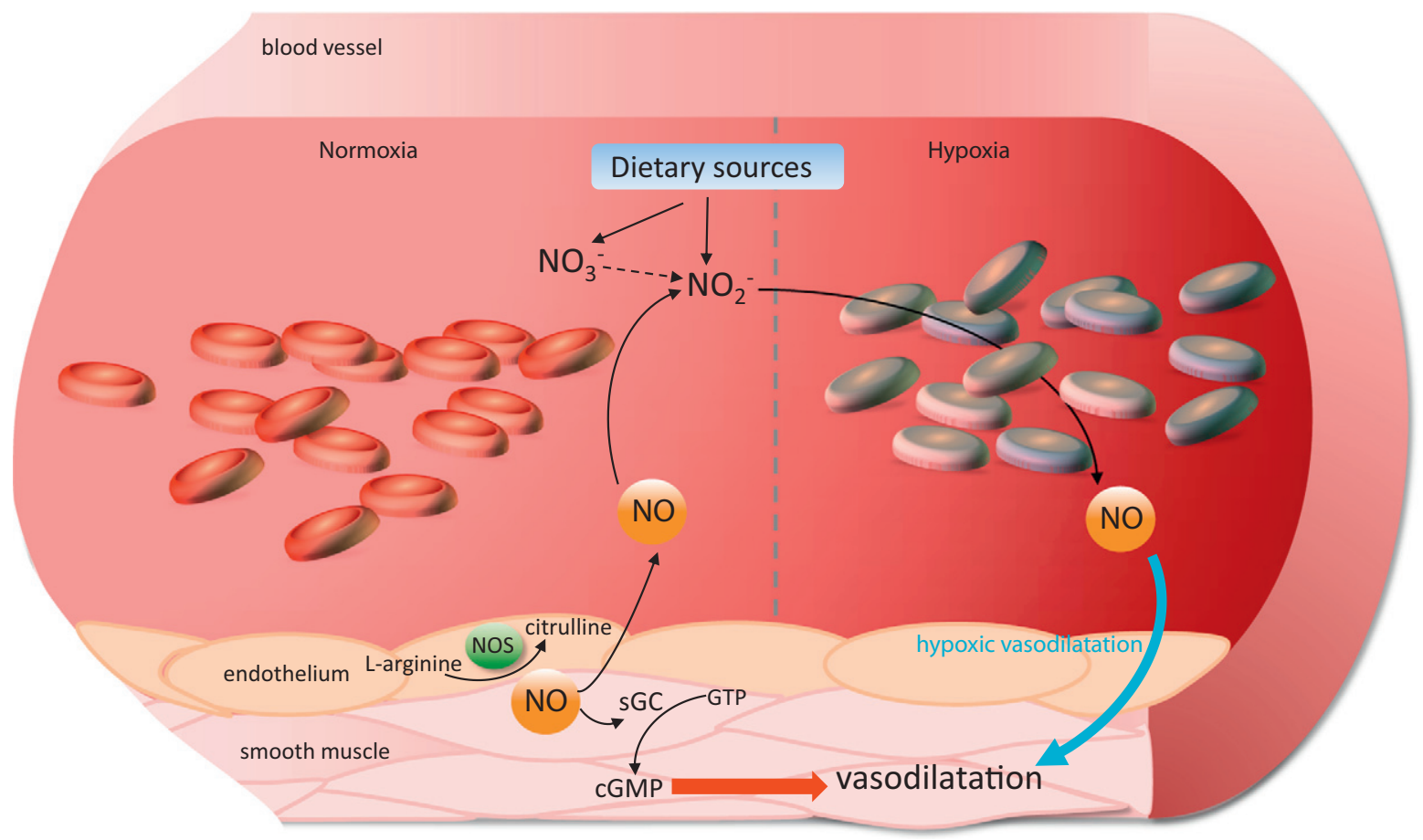

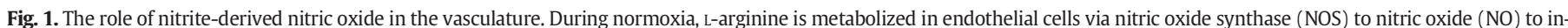

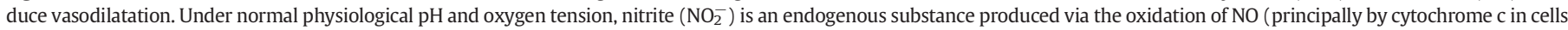

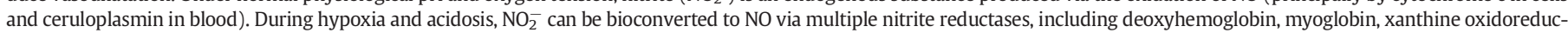
tase, and endothelial NOS to mediate hypoxic vasodilatation. cGMP (cyclic guanosine monophosphate); sGC (soluble guanylyl cyclase); $\mathrm{NO}_{3}^{-}$(nitrate). 
As nitrite delivery continues, increasing amounts of nitrite enter the systemic circulation, gaining access to tissues and blood cells; if the rate of administration exceeds that of elimination, nitrite and its metabolic products (including nitroso and nitrosyl species) begin to accumulate in the vasculature and relaxation ensues. A number of animal experimental results (Bryan et al., 2004; Nagasaka et al., 2008; Perlman et al., 2009) indicate that plasma concentrations of nitrite are uncoupled from those in tissues, suggesting the involvement of additional steps that regulate circulating nitrite concentrations. Thus, short-term infusions of nitrite may differ in effects on pressure and flow from those of longer lasting infusions, and total amounts of nitrite delivered may be as important as local concentrations achieved. If this was true, in vivo nitrite administration regimes might better be compared on the basis of cumulative amounts administered rather than circulating concentrations measured - time will tell.

While initial efforts focussed on the identification of potential nitrite bioactivation pathways (often under very specific reaction conditions with exclusion of oxygen), many more 'leads' emerged than anticipated and likely in operation under physiological conditions. There is a growing appreciation that reduction of nitrite to NO may be mediated by different pathways under different physiological conditions and that the effects of nitrite are sometimes mediated by metabolites other than NO. Moreover, most of the known chemistries proposed to be involved in these processes are rather slow, questioning their overall relevance for physiological regulation. Ultimately, confirmation for the involvement of candidate pathways of bioactivation will require in vivo experimentation. To this end, Hendgen-Cotta et al. (2014) have recently demonstrated a role for $\mathrm{Mb}$ in nitrite-mediated vasodilatation under hypoxic conditions. In addition, there is increasing evidence that nitrite reduction may occur via blood borne protein mediated mechanisms such as RBC eNOS, as demonstrated by Webb et al. (2008a) and Wood et al. (2013), as opposed to or in addition to the currently favoured vascular tissue-derived NO. Also of interest is recent work by Umbrello et al. (2014) who have demonstrated that short-term hypoxic vasodilatation may be mediated by bioactive NO metabolites rather than by free NO. These recent findings are of great interest in terms of the perceived "physiology" of nitrite but require further substantiation and independent confirmation by other groups. The above observations do not exclude the possibility that nitrite bioactivation occurs through as yet unknown enzymatic or chemical mechanisms. There is also much to be considered physiologically in terms of cross-talk between different enzymatic pathways, such as regulation of activity, which will impact on the effects of nitrite and rate of $\mathrm{NO} /$ metabolite production and clearance, and even other chemical entities (carbon monoxide and hydrogen sulfide, for example) much of which has yet to be discovered in vivo.

\section{Potential therapeutic role of nitrite in acute heart failure}

Acute emergence or deterioration of heart failure, with or without the associated development of acute pulmonary edema and the potential need for assisted ventilation, remains a frequent cause of hospital admission with associated morbidity and mortality. Furthermore, there is currently no consensus as to the optimal management of AHF, despite emergence of a large number of potential forms of pharmacotherapy. Many patients with AHF have pre-existent impairment of left ventricular systolic function, and decompensation may reflect intercurrent infection, onset of tachyarrhythmias, recurrent myocardial ischemia and/or poor compliance with prescribed therapy.

Traditionally, AHF has been treated with therapeutic regimens based on the use of diuretics, but it has emerged over the past 20 years that a therapeutic approach centred on the intravenous administration of NO donors to all patients with associated pulmonary edema, together with inclusion of NO donors in the treatment of patients with less severe hemodynamic decompensation, may have substantial advantages (Beltrame et al., 1998; Cotter et al., 1998). On this basis, intravenous infusion of organic nitrates such as GTN or isosorbide dinitrate is commonly utilized as a component of therapy for AHF with pulmonary edema.

While organic nitrate infusions are generally helpful in the immediate treatment of such patients, they impose a number of difficulties. Firstly, organic nitrates such as GTN are absorbed by the plastics material of common intravenous infusion set (bags and infusion tubing) (Cawello \& Bonn, 1983; Hansen \& Spillum, 1991). Hence, unless specialised infusion apparatus is used, it is uncertain whether patients are receiving appropriate GTN infusion rates. Secondly, all organic nitrates are potentially prone to the development of nitrate tolerance during long-term therapy: this is manifest as progressive attenuation of hemodynamic and anti-aggregatory responses to the administered nitrate, with cross-tolerance to other organic nitrates. While some investigators have suggested that nitrate tolerance is also associated with worsening of endothelial dysfunction and attenuation of responsiveness to endogenous NO (that is, cross-tolerance to endothelial NO), overall evidence is more consistent with the concept that nitrate tolerance is engendered primarily by failure of enzymatic release of NO from organic nitrates (Sage et al., 2000). As the probability of emergence of nitrate tolerance is determined essentially by the combination of infusion rate and duration of exposure (Henry et al., 1989), this imposes the need to utilize organic nitrate infusions briefly and with the lowest possible infusion rates.

On the other hand, patients with heart failure, whether acute or chronic, display tissue resistance to the effects of NO (for review see (Chirkov \& Horowitz, 2007)), related primarily to dysfunction of sGC and "scavenging" of $\mathrm{NO}$ by $\mathrm{O}_{2}^{-}$. Hence low organic nitrate infusion rates may not achieve ideal hemodynamic responses. Resorting to intermittent dosing regimes, as sometimes used for antianginal treatment, is impractical for AHF as it bears the risk of inappropriate therapeutic coverage during drug-free intervals.

Infusion of nitrite as a means of treatment for AHF offers a theoretical means of circumventing many of the problems associated with organic nitrate infusion. The relative selectivity for the (hypoxic) venous capacitance vessels and pulmonary vasculature would be an attractive profile in the management of decompensated heart failure. Furthermore the apparent lack of tolerance (Haas et al., 1999; Dejam et al., 2007) would be an additional advantage over organic nitrates (Sage et al., 2000). However sustained high dose nitrite infusion can cause methemoglobinemia and hemolysis (Pluta et al., 2011). To date there have been no large scale studies of nitrite infusion in heart failure.

\section{Potential toxicity of nitrite and nitrate}

Although the role of nitrite and nitrate in cardiovascular health is becoming increasingly apparent, the ingestion of these anions has also been linked to health concerns. There is an abundance of literature on the subject, so we only provide a few pointers for balance here. Dietary nitrate and nitrite can form $\mathrm{N}$-nitrosamines, and countless animal studies have documented low-molecular weight $\mathrm{N}$-nitrosamines to be carcinogenic in numerous organ systems when ingested orally over prolonged periods (Archer, 1989; Mirvish, 1995; Tricker, 1997). In humans, the role of dietary intake of $\mathrm{N}$-nitrosamine compounds and their precursors in the development of cancer is of ongoing interest, but relies largely on observed associations between the intake of certain food classes and cancer risk/death; in many cases, nitrite and nitrate (or preformed N-nitroso compound) intakes were not quantified but estimated using food frequency questionnaires (considering the level of geographical and seasonal variations in nitrate content alone this is not without problems). Some more recent meta-analyses and careful re-assessments of cancer risks and dietary habits in larger cohorts find no association between nitrite and/or nitrate intake and cancer development, but risks may vary depending on cancer types and organs involved. Most likely, matters are much more complicated than hitherto assumed, with environmental and life-style related factors playing important modulatory roles. One very recent study (Dellavalle et al., 
2014) suggests that colon cancer, for example, develops not as a result of increased nitrate intake but is secondary to reduced antioxidant levels (vitamin C, for example, can inhibit nitrosation). Teleologically, it is difficult to see why moderate intake levels of nitrite and nitrate would be linked to cancer development as they occur endogenously in astonishing concentrations in some compartments (e.g. in saliva) and thus are part of our normal body physiology.

Another concern about nitrate is methemoglobinemia. Bacteria in the mouth and gut convert nitrate into nitrite, and nitrite reacts with $\mathrm{Hb}$ to produce methemoglobin, which is no longer able to transport and release oxygen effectively to tissues. Most cases of methemoglobinemia were reported in the 1940s where methemoglobinemia or "baby blue syndrome" was seen in infants fed formula with nitrate contaminated well-water (Powlson et al., 2008). It was later suggested that methemoglobinemia was not caused by nitrate but by fecal bacteria contamination in the well-water or bacterial nitrate reduction in vivo that may have caused the intestinal infection, and this may have been responsible for the nitrate-induced methemoglobinemia in the infants (Hanukoglu \& Danon, 1996; Ward et al., 2005). Of interest, nitrate was used in very high doses (often for weeks) at the beginning of the last century as a diuretic (Butler \& Feelisch, 2008). Recent studies by Pluta et al. (2011) have investigated the safety and feasibility of long-term intravenous infusion of sodium nitrite in healthy subjects. The authors demonstrated that acute intravenous infusion of sodium nitrite was tolerated up to a maximum dose at $267 \mu \mathrm{g} / \mathrm{kg} / \mathrm{h}$, and that the dose-limiting toxicity was reached at $446 \mu \mathrm{g} / \mathrm{kg} / \mathrm{h}$. Toxicity included a transient asymptomatic decrease of MAP and an increase of methemoglobin (above 5\%). Overall, the authors suggested that nitrite could be 'safely infused intravenously at defined concentrations for prolonged intervals'.

Finally, although there are reports to suggest that nitrate and nitrite are harmful when ingested in excess, the same is true for about every other substance essential to mammalian life including glucose, fat and oxygen. It is important to establish limits at which the harm may outweigh the potential benefits, and further research is warranted to investigate what these limits may be for nitrate and nitrite. The extensive monograph by L'Hirondel and L'Hirondel (2002) and several recent articles (Lundberg et al., 2004; Bryan et al., 2012; Kapil et al., 2014) provide a more detailed information for further reading about the potential harmful effects of nitrate and nitrite.

\section{Summary and conclusions}

Nitrite appears to have considerable potential as a therapeutic agent to increase the bioavailability of $\mathrm{NO}$ under certain conditions such as in hypoxia, where endogenous NO production via the L-arginine-NOS-NO pathway may be compromised. Thus, nitrite could conceivably be applied in conditions such as heart failure due to its vasodilatory capacity, apparently without the risk of development of tolerance and headache as documented with organic nitrate treatment, making nitrite perhaps a more acceptable alternative. Oral nitrate administration would appear to represent an attractive vehicle for nitrite delivery in vivo. The beneficial vasodilatory effects apparent with nitrate and nitrite consumption through dietary sources may promote vascular health and ward off CVD. Nitrite therapy is a rapidly expanding area with great potential for improved clinical outcome in patients, however caution is advised in the translation of results obtained in animal experimental models to the clinical setting. A recent multi-centre, double-blind, placebo controlled clinical trial showed that nitrite was ineffective when administered intravenously immediately prior to PPCI in patients presenting with first acute STEMI (Siddiqi et al., 2014). Therefore, we need to be mindful of differences between animal and human physiology as well as inter-individual differences in responsiveness to nitrite between subjects. Moreover, the handling of nitrite (and nitrate) may differ between health and disease, posing additional challenges to effectiveness and applicability of the administered treatment.

\section{Financial support}

This study is supported by the UK Medical Research Council [G1001536].

\section{Conflict of interest statement}

JCB, MF, JDH and MM have no conflict of interest to report. MPF has an ownership interest in a "method of use" patent held for Perhexiline in heart muscle diseases.

\section{References}

Aamand, R., Dalsgaard, T., Jensen, F. B., Simonsen, U., Roepstorff, A., \& Fago, A. (2009). Generation of nitric oxide from nitrite by carbonic anhydrase: a possible link between metabolic activity and vasodilation. Am J Physiol Heart Circ Physiol 297, H2068-H2074.

Aamand, R., Ho, Y. C., Dalsgaard, T., Roepstorff, A., \& Lund, T. E. (1985). Dietary nitrate facilitates an acetazolamide-induced increase in cerebral blood flow during visual stimulation. J Appl Physiol 116, 267-273.

Abudukadier, A., Fujita, Y., Obara, A., Ohashi, A., Fukushima, T., Sato, Y., et al. (2013) Tetrahydrobiopterin has a glucose-lowering effect by suppressing hepatic gluconeogenesis in an endothelial nitric oxide synthase-dependent manner in diabetic mice. Diabetes 62, 3033-3043.

Alzawahra, W. F., Talukder, M.A., Liu, X., Samouilov, A., \& Zweier, J. L. (2008). Heme proteins mediate the conversion of nitrite to nitric oxide in the vascular wall. Am J Physio Heart Circ Physiol 295, H499-H508.

Amezcua, J. L., Palmer, R. M., de Souza, B.M., \& Moncada, S. (1989). Nitric oxide synthesized from L-arginine regulates vascular tone in the coronary circulation of the rabbit Br J Pharmacol 97, 1119-1124.

Amin, A., Choi, S. K., Osman-Elazeik, Y., Badr El-Din, N. K., Kevil, C. G., Navar, L. G., et al (2012). Sodium nitrite therapy rescues ischemia-induced neovascularization and blood flow recovery in hypertension. Pflugers Arch 464, 583-592.

Angelo, M., Singel, D. J., \& Stamler, J. S. (2006). An S-nitrosothiol (SNO) synthase function of hemoglobin that utilizes nitrite as a substrate. Proc Natl Acad Sci U S A 103, 8366-8371.

Appel, L. J., Moore, T. J., Obarzanek, E., Vollmer, W. M., Svetkey, L. P., Sacks, F. M., et al (1997). A clinical trial of the effects of dietary patterns on blood pressure. DASH Collaborative Research Group. N Engl J Med 336, 1117-1124.

Arai, A. (2006). Low-dose nitrite ameliorates myocardial ischemia/reperfusion injury and reduces infarct size in a canine model. Presented at: Role of Nitrite in Physiology, Pathophysiology, and Therapeutics Meeting; September 8-9, 2005; Bethesda, Md. Cited by Gladwin MT, Raat NJ, Shiva S, Dezfulian C, Hogg N, Kim-Shapiro DB, Patel RP. Nitrite as a vascular endocrine nitric oxide reservoir that contributes to hypoxic signaling, cytoprotection, and vasodilation. Am J Physiol Heart Circ Physiol 291, H2026-H2035.

Archer, M. C. (1989). Mechanisms of action of N-nitroso compounds. Cancer Surv 8 , 241-250.

Badejo, A.M., Jr., Hodnette, C., Dhaliwal, J. S., Casey, D. B., Pankey, E., Murthy, S. N., et al. (2010). Mitochondrial aldehyde dehydrogenase mediates vasodilator responses of glyceryl trinitrate and sodium nitrite in the pulmonary vascular bed of the rat. Am J Physiol Heart Circ Physiol 299, H819-H826.

Bahra, M., Kapil, V., Pearl, V., Ghosh, S., \& Ahluwalia, A. (2012). Inorganic nitrate ingestion improves vascular compliance but does not alter flow-mediated dilatation in healthy volunteers. Nitric Oxide 26, 197-202.

Baliga, R. S., Milsom, A. B, Ghosh, S. M. Trinder, S. L, Macallister, R. J. Ahluwalia, A, et al (2012). Dietary nitrate ameliorates pulmonary hypertension: cytoprotective role for endothelial nitric oxide synthase and xanthine oxidoreductase. Circulation 125 2922-2932.

Basu, S., Grubina, R., Huang, J., Conradie, J., Huang, Z., Jeffers, A., et al. (2007). Catalytic generation of $\mathrm{N}_{2} \mathrm{O}_{3}$ by the concerted nitrite reductase and anhydrase activity of hemoglobin. Nat Chem Biol 3, 785-794.

Beltrame, J. F., Zeitz, C. J., Unger, S. A., Brennan, R. J., Hunt, A., Moran, J. L., et al. (1998). Nitrate therapy is an alternative to furosemide/morphine therapy in the management of acute cardiogenic pulmonary edema. J Card Fail 4, 271-279.

Bendall, J. K., Alp, N. J., Warrick, N., Cai, S., Adlam, D., Rockett, K., et al. (2005). Stoichiometric relationships between endothelial tetrahydrobiopterin, endothelial NO synthase (eNOS) activity, and eNOS coupling in vivo: insights from transgenic mice with endothelial-targeted GTP cyclohydrolase 1 and eNOS overexpression. Circ Res 97, 864-871.

Benjamin, N., O'Driscoll, F., Dougall, H., Duncan, C., Smith, L., Golden, M., et al. (1994) Stomach NO synthesis. Nature 368, 502.

Binkerd, E. F., \& Kolari, O. E. (1975). The history and use of nitrate and nitrite in the curing of meat. Food Cosmet Toxicol 13, 655-661.

Blood, A. B., Schroeder, H. J., Terry, M. H., Merrill-Henry, J., Bragg, S. L., Vrancken, K., et al. (2011). Inhaled nitrite reverses hemolysis-induced pulmonary vasoconstriction in newborn lambs without blood participation. Circulation 123, 605-612.

Böger, R. H. (2003). When the endothelium cannot say 'NO' anymore. ADMA, an endogenous inhibitor of NO synthase, promotes cardiovascular disease. Eur Heart J 24, 1901-1902.

Bondonno, C. P., Yang, X., Croft, K. D., Considine, M. J., Ward, N. C., Rich, L., et al. (2012) Flavonoid-rich apples and nitrate-rich spinach augment nitric oxide status and improve endothelial function in healthy men and women: a randomized controlled trial. Free Radic Biol Med 52, 95-102. 
Booth, J. (1977). A short history of blood pressure measurement. Proc R Soc Med 70, 793-799.

Bryan, N. S., Alexander, D.D., Coughlin, J. R., Milkowski, A. L., \& Boffetta, P. (2012). Ingested nitrate and nitrite and stomach cancer risk: an updated review. Food Chem Toxicol 50, 3646-3665.

Bryan, N. S., Fernandez, B. O., Bauer, S. M., Gauria-Saura, M. F., Milsom, A. B., Rassaf, T., et al. (2005). Nitrite is a signaling molecule and regulator of gene expression in mammalian tissues. Nat Chem Biol 1, 290-297.

Bryan, N. S., Rassaf, T., Maloney, R. E., Rodriguez, C. M., Saijo, F., Rodriguez, J. R., et al. (2004). Cellular targets and mechanisms of nitros(yl)ation: an insight into their nature and kinetics in vivo. Proc Natl Acad Sci U S A 101, 4308-4313.

Bueno, M., Wang, J., Mora, A. L., \& Gladwin, M. T. (2013). Nitrite signaling in pulmonary hypertension: mechanisms of bioactivation, signaling, and therapeutics. Antioxid Redox Signal 18, 1797-1809.

Burney, S., Caulfield, J. L., Niles, J. C., Wishnok, J. S., \& Tannenbaum, S. R. (1999). The chemistry of DNA damage from nitric oxide and peroxynitrite. Mutat Res 424, 37-49.

Butler, A.R., \& Feelisch, M. (2008). Therapeutic uses of inorganic nitrite and nitrate: from the past to the future. Circulation 117, 2151-2159.

Cai, H., \& Harrison, D.G. (2000). Endothelial dysfunction in cardiovascular diseases the role of oxidant stress. Circ Res 87

Cantu-Medellin, N., \& Kelley, E. E. (2013). Xanthine oxidoreductase-catalyzed reactive species generation: a process in critical need of reevaluation. Redox Biol 1, 353-358.

Cao, Z., Bell, J. B., Mohanty, J. G., Nagababu, E., \& Rifkind, J. M. (2009). Nitrite enhances RBC hypoxic ATP synthesis and the release of ATP into the vasculature: a new mechanism for nitrite-induced vasodilation. Am J Physiol Heart Circ Physiol 297, H1494-H1503.

Casey, D. B., Badejo, A.M., Jr., Dhaliwal, J. S., Murthy, S. N., Hyman, A. L., Nossaman, B.D. et al. (2009). Pulmonary vasodilator responses to sodium nitrite are mediated by an allopurinol-sensitive mechanism in the rat. Am J Physiol Heart Circ Physiol 296, H524-H533.

Cawello, W., \& Bonn, R. (1983). The effect on biologic availability of the choice of infusion material in nitroglycerin therapy. Arzneimittelforschung 33, 595-597.

Cermak, N. M., Res, P., Stinkens, R., Lundberg, J. O., Gibala, M. J., \& van Loon, L. J. C. (2012). No improvement in endurance performance after a single dose of beetroot juice. Int Sport Nutr Exerc Metab 22, 470-478.

Chirkov, Y. Y., \& Horowitz, J.D. (2007). Impaired tissue responsiveness to organic nitrates and nitric oxide: a new therapeutic frontier? Pharmacol Ther 116, 287-305.

Christensen, P.M., Nyberg, M., \& Bangsbo, J. (2013). Influence of nitrate supplementation on $\mathrm{VO}_{2}$ kinetics and endurance of elite cyclists. Scand J Med Sci Sports 23, e21-e31.

Clementi, E., Brown, G. C., Feelisch, M., \& Moncada, S. (1998). Persistent inhibition of cell respiration by nitric oxide: crucial role of S-nitrosylation of mitochondrial complex and protective action of glutathione. Proc Natl Acad Sci U S A 95, 7631-7636.

Cortese-Krott, M. M., Rodriguez-Mateos, A., Thasian-Sivarajah, S., Krenz, T., Horn, P., Krisp, C., et al. (2012). Human red blood cells at work: identification and visualization of erythrocytic eNOS activity in health and disease. Blood 15, 4229-4237.

Corti, P., Tejero, J., \& Gladwin, M. T. (2013). Evidence mounts that red cells and deoxyhemoglobin can reduce nitrite to bioactive $\mathrm{NO}$ to mediate intravascular endocrine NO signaling: commentary on "Anti-platelet effects of dietary nitrate in healthy volunteers: involvement of cGMP and influence of sex". Free Radic Biol Med 65, 1518-1520.

Cosby, K., Partovi, K. S., Crawford, J. H., Patel, R. P., Reiter, C. D., Martyr, S., et al. (2003). Nitrite reduction to nitric oxide by deoxyhemoglobin vasodilates the human circulation. Nat Med 9, 1498-1505.

Cotter, G., Metzkor, E., Kaluski, E., Faigenberg, Z., Miller, R., Simovitz, A., et al. (1998) Randomised trial of high-dose isosorbide dinitrate plus low-dose furosemide versus high-dose furosemide plus low-dose isosorbide dinitrate in severe pulmonary oedema. Lancet 351, 389-393.

Crawford, J. H., Isbell, T. S., Huang, Z., Shiva, S., Chacko, B. K., Schechter, A. N., et al. (2006) Hypoxia, red blood cells, and nitrite regulate NO-dependent hypoxic vasodilation. Blood 107, 566-574.

Dalsgaard, T., Simonsen, U., \& Fago, A. (2007). Nitrite-dependent vasodilation is facilitated by hypoxia and is independent of known NO-generating nitrite reductase activities. Am J Physiol Heart Circ Physiol 292, H3072-H3078.

Danser, A. H., van Kats, J. P., Admiraal, P. J., Derkx, F. H., Lamers, J. M., Verdouw, P. D., et al (1994). Cardiac renin and angiotensins. Uptake from plasma versus in situ synthesis. Hypertension 24, 37-48.

Darley-Usmar, V. M., Hogg, N., O'Leary, V. J., Wilson, M. T., \& Moncada, S. (1992). The simultaneous generation of superoxide and nitric oxide can initiate lipid peroxidation in human low density lipoprotein. Free Radic Res Commun 17, 9-20.

de Berrazueta, J. R., Guerra-Ruiz, A., Garcia-Unzueta, M. T., Toca, G. M., Laso, R. S., de Adana, M. S., et al. (2010). Endothelial dysfunction, measured by reactive hyperaemia using strain-gauge plethysmography, is an independent predictor of adverse outcome in heart failure. Eur J Heart Fail 12, 477-483.

Deem, S., Min, J. H., Moulding, J.D., Eveland, R., \& Swenson, E. R. (2007). Red blood cells prevent inhibition of hypoxic pulmonary vasoconstriction by nitrite in isolated, perfused rat lungs. Am J Physiol Heart Circ Physiol 292, H963-H970.

Dejam, A., Hunter, C. J., Pelletier, M. M., Hsu, L. L., Machado, R. F., Shiva, S., et al. (2005). Erythrocytes are the major intravascular storage sites of nitrite in human blood. Blood 106, 734-739.

Dejam, A., Hunter, C. J., Tremonti, C., Pluta, R. M., Hon, Y. Y., Grimes, G., et al. (2007). Nitrite infusion in humans and nonhuman primates: endocrine effects, pharmacokinetics, and tolerance formation. Circulation 116, 1821-1831.

Delaney, C. A., Green, M. H. L., Lowe, J. E., \& Green, I. C. (1993). Endogenous nitric oxide induced by interleukin-1 in rat islets of Langerhans and HIT-T15 cells causes significant DNA damage as measured by the 'comet' assay. FEBS Lett 333, 291-295.

Dellavalle, C. T., Xiao, Q., Yang, G., Shu, X. O., Aschebrook-Kilfoy, B., Zheng, W., et al. (2014). Dietary nitrate and nitrite intake and risk of colorectal cancer in the Shanghai Women's Health Study. Int J Cancer 134, 2917-2926.
Demoncheaux, E. A. G., Higenbottam, T. W., Foster, P. J., Borland, C. D. R., Smith, A. P. L., Marriott, et al. (2002). Circulating nitrite anions are a directly acting vasodilator and are donors for nitric oxide. Clin Sci 102, 77-83.

deRojas-Walker, T., Tamir, S., Ji, H., Wishnok, J. S., \& Tannenbaum, S. R. (1995). Nitric oxide induces oxidative damage in addition to deamination in macrophage DNA. Chem Res Toxicol 8, 473-477.

Dezfulian, C., Raat, N., Shiva, S., \& Gladwin, M. T. (2007). Role of the anion nitrite in ischemia-reperfusion cytoprotection and therapeutics. Cardiovasc Res 75, 327-338.

Dias-Junior, C. A., Gladwin, M. T., \& Tanus-Santos, J. E. (2006). Low-dose intravenous nitrite improves hemodynamics in a canine model of acute pulmonary thromboembolism. Free Radic Biol Med 41, 1764-1770.

Doel, J. J., Benjamin, N., Hector, M. P., Rogers, M., \& Allaker, R. P. (2005). Evaluation of bacterial nitrate reduction in the human oral cavity. Eur J Oral Sci 113, 14-19.

Duranski, M. R., Greer, J. J., Dejam, A., Jaganmohan, S., Hogg, N., Langston, W., et al. (2005). Cytoprotective effects of nitrite during in vivo ischemia-reperfusion of the heart and liver. J Clin Invest 115, 1232-1240.

Erusalimsky, J.D., \& Moncada, S. (2007). Nitric oxide and mitochondrial signaling: from physiology to pathophysiology. Arterioscler Thromb Vasc Biol 27, 2524-2531.

Espejo-Herrera, N., Kogevinas, M., Castano-Vinyals, G., Aragones, N., Boldo, E., Ardanaz, E., et al. (2013). Nitrate and trace elements in municipal and bottled water in Spain. Gac Sanit 27, 156-160.

Feelisch, M., Fernandez, B. O., Bryan, N. S., Garcia-Saura, M. F., Bauer, S., Whitlock, D. R. et al. (2008). Tissue processing of nitrite in hypoxia: an intricate interplay of nitric oxide-generating and -scavenging systems. J Biol Chem 283, 33927-33934.

Forstermann, U., \& Munzel, T. (2006). Endothelial nitric oxide synthase in vascular disease: from marvel to menace. Circulation 113, 1708-1714.

Furchgott, R. F., \& Bhadrakom, S. (1953). Reactions of strips of rabbit aorta to epinephrine, isopropylarterenol, sodium nitrite and other drugs. J Pharmacol Exp Ther 108, $129-143$.

Furchgott, R. F., Ehrreich, S. J., \& Greenblatt, E. (1961). The photoactivated relaxation of smooth muscle of rabbit aorta. J Gen Physiol 44, 499-519.

Furchgott, R. F., \& Zawadski, J. V. (1980). The obligatory role of endothelial cells in the relaxation of arterial smooth muscle by acetylcholine. Nature 288, 373-376.

Gherasim, C., Yadav, P. K., Kabil, O., Niu, W. N., \& Banerjee, R. (2014). Nitrite reductase activity and inhibition of $\mathrm{H}_{2} \mathrm{~S}$ biogenesis by human cystathione ß-synthase. PLoS One 9, e85544.

Ghosh, S. M., Kapil, V., Fuentes-Calvo, I., Bubb, K. J., Pearl, V., Milsom, A. B., et al. (2013). Enhanced vasodilator activity of nitrite in hypertension: critical role for erythrocytic xanthine oxidoreductase and translational potential. Hypertension 61, 1091-1102.

Gilchrist, M., Winyard, P. G., \& Benjamin, N. (2010). Dietary nitrate - good or bad? Nitric Oxide 22, 104-109.

Gladwin, M. T., Grubina, R., \& Doyle, M. P. (2009). The new chemical biology of nitrite reactions with hemoglobin: R-state catalysis, oxidative denitrosylation, and nitrite reductase/anhydrase. Acc Chem Res 20, 157-167.

Gladwin, M. T., \& Kim-Shapiro, D. B. (2008). The functional nitrite reductase activity of the heme-globins. Blood 112, 2636-2647.

Gladwin, M. T., Shelhamer, J. H., Schechter, A. N., Pease-Fye, M. E., Waclawiw, M.A., Panza, J. A., et al. (2000). Role of circulating nitrite and S-nitrosohemoglobin in the regulation of regional blood flow in humans. Proc Natl Acad Sci U S A 97, 11482-11487.

Golwala, N. H., Hodenette, C., Murthy, S. N., Nossaman, B.D., \& Kadowitz, P. J. (2009). Vascular responses to nitrite are mediated by xanthine oxidoreductase and mitochondrial aldehyde dehydrogenase in the rat. Can J Physiol Pharmacol 87, 1095-1101.

Govoni, M., Jansson, E. A., Weitzberg, E., \& Lundberg, J. O. (2008). The increase in plasma nitrite after a dietary nitrate load is markedly attenuated by an antibacterial mouthwash. Nitric Oxide 19, 333-337.

Griendling, K. K., \& Fitzgerald, G. A. (2003). Oxidative stress and cardiovascular injury: part I: basic mechanisms and in vivo monitoring of ROS. Circulation 108, 1912-1916.

Griffith, T. M., Edwards, D. H., Lewis, M. J., Newby, A.C., \& Henderson, A. H. (1984). The nature of endothelium-derived vascular relaxant factor. Nature 308, 645-647.

Grosso, G., Mistretta, A., Frigiola, A., Gruttadauria, S., Biondi, A., Basile, F., et al. (2014). Mediterranean diet and cardiovascular risk factors: a systematic review. Crit Rev Food Sci Nutr 54, 593-610

Guy, R. A., Maguire, G. F., Crandall, I., Connelly, P. W., \& Kain, K. C. (2001). Characterization of peroxynitrite-oxidized low density lipoprotein binding to human CD36. Atherosclerosis 155, 19-28.

Haas, M., Classen, H. G., Thoni, H., Classen, U. G., \& Drescher, B. (1999). Persistent antihypertensive effect of oral nitrite supplied up to one year via the drinking water in spontaneously hypertensive rats. Arzneimittelforschung 49, 318-323.

Hagen, T., Taylor, C. T., Lam, F., \& Moncada, S. (2003). Redistribution of intracellular oxygen in hypoxia by nitric oxide: effect on HIF1alpha. Science 302, 1975-1978.

Hansen, H. C., \& Spillum, A. (1991). Loss of nitroglycerin during passage through two different infusion sets. Acta Pharm Nord 3, 131-136.

Hanukoglu, A., \& Danon, P. N. (1996). Endogenous methemoglobinemia associated with diarrheal disease in infancy. J Pediatr Gastroenterol Nutr 23, 1-7.

Harrison, D.G. (1997). Endothelial function and oxidant stress. Clin Cardiol 20, 11-17.

Hendgen-Cotta, U. B., Kelm, M., \& Rassaf, T. (2014). Myoglobin's novel role in nitriteinduced hypoxic vasodilation. Trends Cardiovasc Med 24, 69-74.

Henry, P. J., Horowitz, J.D., \& Louis, W. J. (1989). Determinants of in vitro nitroglycerin tolerance induction and reversal: influence of dose regimen, nitrate-free period, and sulfhydryl supplementation. J Cardiovasc Pharmacol 14, 31-37.

Hirase, T., \& Node, K. (2012). Endothelial dysfunction as a cellular mechanism for vascular failure. Am J Physiol Heart Circ Physiol 302, H499-H505.

Hobbs, D. A., Goulding, M. G., Nguyen, A., Malaver, T., Walker, C. F., George, T. W., et al. (2013). Acute ingestion of beetroot bread increases endothelium-independent vasodilation and lowers diastolic blood pressure in healthy men: a randomized controlled trial. J Nutr 143, 1399-1405. 
Hord, N. G. (2011). Dietary nitrates, nitrites, and cardiovascular disease. Curr Atheroscler Rep 13, 484-492.

Huang, Z., Shiva, S., Kim-Shapiro, D. B., Patel, R. P., Ringwood, L. A., Irby, C. E., et al. (2005). Enzymatic function of hemoglobin as a nitrite reductase that produces NO under allosteric control. J Clin Invest 115, 2099-2107.

Hunter, C. J., Dejam, A., Blood, A. B., Shields, H., Kim-Shapiro, D., Machado, R. F., et al. (2004). Inhaled nebulized nitrite is a hypoxia-sensitive NO-dependent selective pulmonary vasodilator. Nat Med 10,1122-1127.

Ignarro, L. J. (1999). Nitric oxide: a unique endogenous signaling molecule in vascular biology. Biosci Rep 19, 51-71.

Ignarro, L. J., Buga, G. M., Wood, K. S., Byrns, R. E., \& Chaudhuri, G. (1987). Endotheliumderived relaxing factor produced and released from artery and vein is nitric oxide. Proc Natl Acad Sci U S A 84, 9265-9269.

Ignarro, L. J., Lippton, H., Edwards, J. C., Baricos, W. H., Hyman, A. L., Kadowitz, P. J., et al. (1981). Mechanism of vascular smooth-muscle relaxation by organic nitrates, nitrites, nitroprusside and nitric-oxide - evidence for the involvement of Snitrosothiols as active intermediates. J Pharmacol Exp Ther 218, 739-749.

Ingram, T. E., Pinder, A. G., Bailey, D.M., Fraser, A. G., \& James, P. E. (2010). Low-dose sodium nitrite vasodilates hypoxic pulmonary vasculature by a means that is not dependent on a simultaneous elevation in plasma nitrite. Am J Physiol Heart Circ Physiol 298, H331-H339.

Isbell, T. S., Gladwin, M. T., \& Patel, R. P. (2007). Hemoglobin oxygen fractional saturation regulates nitrite-dependent vasodilation of aortic ring bioassays. Am J Physiol Heart Circ Physiol 293, H2565-H2572.

Jacobson, A., Yan, C., Gao, Q., Rincon-Skinner, T., Rivera, A., Edwards, J., et al. (2007). Aging enhances pressure-induced arterial superoxide formation. Am J Physiol Heart Circ Physiol 293, H1344-H1350.

Jeffers, A., Xu, X., Huang, K. T., Cho, M., Hogg, N., Patel, R. P., et al. (2005). Hemoglobin mediated nitrite activation of soluble guanylate cyclase. Comp Biochem Physiol A Mol Integr Physiol 142, 130-135.

Joshi, M. S., Ferguson, T. B., Jr., Han, T. H., Hyduke, D. R., Liao, J. C., Rassaf, T., et al. (2002). Nitric oxide is consumed, rather than conserved, by reaction with oxyhemoglobin under physiological conditions. Proc Natl Acad Sci U S A 99, 10341-10346.

Joshipura, K. J., Hu, F. B., Manson, J. E., Stampfer, M. J., Rimm, E. B., Speizer, F. E., et al. (2001). The effect of fruit and vegetable intake on risk for coronary heart disease. Ann Intern Med 134, 1106-1114.

Kapil, V., Haydar, S. M.A., Pearl, V., Lundberg, J. O., Weitzberg, E., \& Ahluwalia, A. (2013). Physiological role for nitrate-reducing oral bacteria in blood pressure control. Free Radic Biol Med 55, 93-100.

Kapil, V., Milsom, A. B., Okorie, M., Maleki-Toyserkani, S., Akram, F., Rehman, F., et al. (2010). Inorganic nitrate supplementation lowers blood pressure in humans: role for nitrite-derived NO. Hypertension 56, 274-281.

Kapil, V., Webb, A. J., \& Ahluwalia, A. (2010). Inorganic nitrate and the cardiovascular system. Heart 96, 1703-1709.

Kapil, V., Weitzberg, E., Lundberg, J. O., \& Ahluwalia, A. (2014). Clinical evidence demonstrating the utility of inorganic nitrate in cardiovascular health. Nitric Oxide 38C, 45-57.

Kim, H. J., \& Conca, K. R. (1990). Determination of nitrite in cured meats by ionexclusion chromatography with electrochemical detection. J Assoc Off Anal Chem 73, 561-564.

Kim-Shapiro, D. B., \& Gladwin, M. T. (2013). Mechanisms of nitrite bioactivation. Nitric Oxide 38C, 58-68.

Kleinbongard, P., Dejam, A., Lauer, T., Rassaf, T., Schindler, A., Picker, O., et al. (2003). Plasma nitrite reflects constitutive nitric oxide synthase activity in mammals. Free Radic Biol Med 35, 790-796.

Knobeloch, L., Gorski, P., Christenson, M., \& Anderson, H. (2013). Private drinking water quality in rural Wisconsin. J Environ Health 75, 16-20.

Koh, E., Charoenprasert, S., \& Mitchell, A. E. (2012). Effect of organic and conventional cropping systems on ascorbic acid, vitamin C, flavonoids, nitrate, and oxalate in 27 varieties of spinach (Spinacia oleracea L.). J Agric Food Chem 60, 3144-3150.

Lansley, K. E., Winyard, P. G., Bailey, S. J., Vanhatalo, A., Wilkerson, D. P., Blackwell, J. R., et al. (2011). Acute dietary nitrate supplementation improves cycling time trial performance. Med Sci Sports Exerc 43, 1125-1131.

Larrousse, M., Bragulat, E., Segarra, M., Sierra, C., Coca, A., \& de La Sierra, A. (2006). Increased levels of atherosclerosis markers in salt-sensitive hypertension. Am J Hypertens 19, 87-93.

Larsen, F. J., Ekblom, B., Sahlin, K., Lundberg, J. O., \& Weitzberg, E. (2006). Effects of dietary nitrate on blood pressure in healthy volunteers. N Engl J Med 355, 2792-2793.

Larsen, F. J., Schiffer, T. A., Borniquel, S., Sahlin, K., Ekblom, B., Lundberg, J. O., et al. (2011). Dietary inorganic nitrate improves mitochondrial efficiency in humans. Cell Metab 13, 149-159.

Lauer, T., Preik, M., Rassaf, T., Strauer, B. E., Deussen, A., Feelisch, M., et al. (2001). Plasma nitrite rather than nitrate reflects regional endothelial nitric oxide synthase activity but lacks intrinsic vasodilator action. Proc Natl Acad Sci U S A 98, 12814-12819.

L'Hirondel, J., \& L'Hirondel, J. -L. (2002). Nitrate and Man: Toxic, Harmless or Beneficial? Wallingford UK: CABI Publishing.

Li, H., Cui, H., Kundu, T. K., Alzawahra, W., \& Zweier, J. L. (2008). Nitric oxide production from nitrite occurs primarily in tissues not in the blood; critical role of xanthine oxidase and aldehyde oxidase. J Biol Chem 283, 17855-17863.

Li, H., Samouilov, A., Liu, X., \& Zweier, J. L. (2003). Characterization of the magnitude and kinetics of xanthine oxidase-catalyzed nitrate reduction: evaluation of its role in nitrite and nitric oxide generation in anoxic tissues. Biochemistry 42, 1150-1159.

Lidder, S., \& Webb, A. J. (2012). Vascular effects of dietary nitrate (as found in green leafy vegetables and beetroot) via the nitrate-nitrite-nitric oxide pathway. Br J Clin Pharmacol 75, 677-696.

Liu, D., Fernandez, B. O., Hamilton, A., Lang, N. N., Gallagher, J. M., Newby, D. E., et al. (2014). UVA irradiation of human skin vasodilates arterial vasculature and lowers blood pressure independently of nitric oxide synthase. J Invest Dermatol 134(7) 1839-1846.

Loscalzo, J., \& Welch, G. (1995). Nitric oxide and its role in the cardiovascular system. Prog Cardiovasc Dis 38, 87-104.

Lundberg, J. O., Feelisch, M., Bjorne, H., Jansson, E. A., \& Weitzberg, E. (2006) Cardioprotective effects of vegetables: is nitrate the answer. Nitric Oxide 15, 359-362.

Lundberg, J. O., Gladwin, M. T., Ahluwalia, A., Benjamin, N., Bryan, N. S., Butler, A., et al. (2009). Nitrate and nitrite in biology, nutrition and therapeutics. Nat Chem Biol 5, 865-869.

Lundberg, J. O., \& Govoni, M. (2004). Inorganic nitrate is a possible source for systemic generation of nitric oxide. Free Radic Biol Med 37, 395-400.

Lundberg, J. O., \& Weitzberg, E. (2010). NO-synthase independent NO generation in mammals. Biochem Biophys Res Commun 396, 39-45.

Lundberg, J. O., Weitzberg, E., Cole, J. A., \& Benjamin, N. (2004). Nitrate, bacteria and human health. Nat Rev Microbiol 2, 593-602.

Lundberg, J. O., Weitzberg, E., \& Gladwin, M. T. (2008). The nitrate-nitrite-nitric oxide pathway in physiology and therapeutics. Nat Rev Drug Discov 7, 156-167.

Lundberg, J. O., Weitzberg, E., Lundberg, J. M., \& Alving, K. (1994). Intragastric nitric oxide production in humans: measurements in expelled air. Gut 35, 1543-1546.

Machha, A., \& Schechter, A. N. (2012). Inorganic nitrate: a major player in cardiovascular health benefits of vegetables. Nutr Rev 70, 367-372.

Mack, A. K., McGowan Ii, V. R., Tremonti, C. K., Ackah, D., Barnett, C., Machado, R. F., et al. (2008). Sodium nitrite promotes regional blood flow in patients with sickle cell disease: a phase I/II study. Br J Haematol 142, 971-978.

Maher, A.R., Arif, S., Madhani, M., Abozguia, K., Ahmed, I., Fernandez, B. O., et al. (2013) Impact of chronic congestive heart failure on pharmacokinetics and vasomotor effects of infused nitrite. Br J Pharmacol 169, 659-670.

Maher, A.R., Milsom, A. B., Gunaruwan, P., Abozguia, K., Ahmed, I., Weaver, R. A., et al. (2008). Hypoxic modulation of exogenous nitrite-induced vasodilation in humans. Circulation 117, 670-677.

Margaritis, M., Antonopoulos, A. S., Digby, J., Lee, R., Reilly, S., Coutinho, P., et al. (2013) Interactions between vascular wall and perivascular adipose tissue reveal nove roles for adiponectin in the regulation of endothelial nitric oxide synthase function in human vessels, clinical perspective. Circulation 127, 2209-2221.

Marsh, N., \& Marsh, A. (2000). A short history of nitroglycerine and nitric oxide in pharmacology and physiology. Clin Exp Pharmacol Physiol 27, 313-319.

Martin, D. S., Gilbert-Kawai, E. T., Meale, P.M., Fernandez, B. O., Cobb, A., Khosravi, M., et al. (2013). Design and conduct of 'Xtreme Alps': a double-blind, randomised controlled study of the effects of dietary nitrate supplementation on acclimatisation to high altitude. Contemp Clin Trials 36, 450-459.

Mathers, C. D., \& Loncar, D. (2006). Projections of global mortality and burden of disease from 2002 to 2030. PLoS Med 3, e442.

Matsunaga, K., \& Furchgott, R. F. (1989). Interactions of light and sodium nitrite in producing relaxation of rabbit aorta. J Pharmacol Exp Ther 248, 687-695.

Matsunaga, K., \& Furchgott, R. F. (1991). Responses of rabbit aorta to nitric oxide and superoxide generated by ultraviolet irradiation of solutions containing inorganic nitrite. J Pharmacol Exp Ther 259, 1140-1146.

Mayer, B., Schmidt, K., Humbert, R., \& Bohme, E. (1989). Biosynthesis of endothelium derived relaxing factor: a cytosolic enzyme in porcine aortic endothelial cells $\mathrm{Ca}^{2+}$. dependently converts L-arginine into an activator of soluble guanylate cyclase. Biochem Biophys Res Commun 164, 678-685.

McKnight, G. M., Smith, L. M., Drummond, R. S., Duncan, C. W., Golden, M., \& Benjamin, N. (1997). Chemical synthesis of nitric oxide in the stomach from dietary nitrate in humans. Gut 40, 211-214.

Meah, M. N., Harrison, N., \& Davies, A. (1994). Nitrate and nitrite in foods and the diet Food Addit Contam 11, 519-532.

Michel, T., \& Feron, O. (1997). Nitric oxide synthases: which, where, how and why. J Clin Invest 100, 2146-2152.

Minneci, P. C., Deans, K. J., Shiva, S., Zhi, H., Banks, S. M., Kern, S., et al. (2008). Nitrite reductase activity of hemoglobin as a systemic nitric oxide generator mechanism to detoxify plasma hemoglobin produced during hemolysis. Am J Physiol Heart Circ Physiol 295, H743-H754.

Mirvish, S. S. (1995). Role of N-nitroso compounds (NOC) and N-nitrosation in etiology of gastric, esophageal, nasopharyngeal and bladder cancer and contribution to cancer of known exposures to NOC. Cancer Lett 93, 17-48.

Modin, A., Björne, H., Herulf, M., Alving, K., Weitzberg, E., \& Lundberg, J. O. (2001). Nitritederived nitric oxide: a possible mediator of 'acidic-metabolic' vasodilation. Acta Physiol Scand 171, 9-16.

Moncada, S., \& Higgs, A. (1993). The L-arginine-nitric oxide pathway. N Engl J Med 329, 202-212.

Moncada, S., \& Palmer, R. M. J. (1990). The L-arginine:nitric oxide pathway in the vesse wall. In S. Moncada, \& E. A. Higgs (Eds.), Nitric Oxide from L-Arginine: A Bioregulatory System (pp. 19-33). Amsterdam: Elsevier.

Moncada, S., Palmer, R. M. J., \& Higgs, E. A. (1988). The discovery of nitric-oxide as the endogenous nitrovasodilator. Hypertension 12, 365-372.

Moncada, S., \& Vane, J. R. (1981). Prostacyclin: its biosynthesis, actions and clinical potential. Philos Trans R Soc Lond B Biol Sci 294, 305-329.

Mulsch, A., Bassenge, E., \& Busse, R. (1989). Nitric oxide synthesis in endothelial cytosol evidence for a calcium-dependent and a calcium-independent mechanism. Naunyn Schmiedebergs Arch Pharmacol 340, 767-770

Murad, F., Mittal, C. K., Arnold, W. P., Katsuki, S., \& Kimura, H. (1978). Guanylate cyclase: activation by azide, nitro compounds, nitric oxide, and hydroxyl radical and inhibition by hemoglobin and myoglobin. Adv Cyclic Nucleotide Res 9, 145-158.

Nagasaka, Y., Fernandez, B. O., Garcia-Saura, M. F., Petersen, B., Ichinose, F., Bloch, K. D., et al. (2008). Brief periods of nitric oxide inhalation protect against myocardial ischemia-reperfusion injury. Anesthesiology 109, 675-682. 
Needleman, P., Moncada, S., Bunting, S., Vane, J. R., Hamberg, M., \& Samuelsson, B. (1976) Identification of an enzyme in platelet microsome which generates thromboxane A from prostaglandin endoperoxides. Nature 261, 558-560.

Nemčić-Jurec, J., Konjačić, M., \& Jazbec, A. (2013). Monitoring of nitrates in drinking water from agricultural and residential areas of Podravina and Prigoje (Croatia). Environ Monit Assess 185, 9509-9520.

Ormerod, J. O., Ashrafian, H., Maher, A.R., Arif, S., Steeples, V., Born, G. V., et al. (2011). The role of vascular myoglobin in nitrite-mediated blood vessel relaxation. Cardiovasc Res 89, 560-565.

Padilla, J., Jenkins, N. T., Laughlin, M. H., \& Fadel, P. J. (2014). Blood pressure regulation VIII: resistance vessel tone and implications for a pro-atherogenic conduit artery endothelial cell phenotype. Eur J Appl Physiol 114(3), 531-544.

Palmer, R. M., Ashton, D. S., \& Moncada, S. (1988). Vascular endothelial cells synthesize nitric oxide from L-arginine. Nature 333, 664-666.

Pannala, A. S., Mani, A.R., Spencer, J. P., Skinner, V., Bruckdorfer, K. R., Moore, K. P., et al. (2003). The effect of dietary nitrate on salivary, plasma, and urinary nitrate metabolism in humans. Free Radic Biol Med 34, 576-584

Park, J. W., Piknova, B., Huang, P. L., Noguchi, C. T., \& Schechter, A. N. (2013). Effect of blood nitrite and nitrate levels on murine platelet function. PLoS One 8, e55699.

Peacock, O., Tjonna, A. E., James, P., Wisloff, U., Welde, B., Bohlke, N., et al. (2012). Dietary nitrate does not enhance running performance in elite cross-country skiers. Med Sci Sports Exerc 44, 2213-2219.

Perlman, D. H., Bauer, S. M., Ashrafian, H., Bryan, N. S., Garcia-Saura, M. F., Lim, C. C., et al. (2009). Mechanistic insights into nitrite-induced cardioprotection using an integrated metabolomic/proteomic approach. Circ Res 104, 796-804.

Petersson, J., Carlstrom, M., Schreiber, O., Phillipson, M., Christoffersson, G., Jagare, A., et al. (2009). Gastroprotective and blood pressure lowering effects of dietary nitrate are abolished by an antiseptic mouthwash. Free Radic Biol Med 46, 1068-1075.

Pinder, A. G., Pittaway, E., Morris, K., \& James, P. E. (2009). Nitrite directly vasodilates hypoxic vasculature via nitric oxide-dependent and -independent pathways. $\mathrm{Br} J$ Pharmacol 157, 1523-1530.

Pinheiro, L. C., Montenegro, M. F., Amaral, J. H., Ferreira, G. C., Oliveira, A.M., \& Tanus-Santos, J. E. (2012). Increase in gastric pH reduces hypotensive effect of oral sodium nitrite in rats. Free Radic Biol Med 53, 701-709.

Pluta, R. M., Oldfield, E. H., Bakhtian, K. D., Fathi, A.R., Smith, R. K., Devroom, H. L., et al. (2011). Safety and feasibility of long-term intravenous sodium nitrite infusion in healthy volunteers. PLoS One 6, e14504.

Pou, S., Pou, W. S., Bredt, D. S., Snyder, S. H., \& Rosen, G. M. (1992). Generation of superoxide by purified brain nitric oxide synthase. J Biol Chem 267, 24173-24176.

Powlson, D. S., Addiscott, T. M., Benjamin, N., Cassman, K. G., de Kok, T. M., van Grinsven, H., et al. (2008). When does nitrate become a risk for humans? J Environ Qual 37, 291-295.

Qin, L., Liu, X., Sun, Q., Fan, Z., Xia, D., Ding, G., et al. (2012). Sialin (SLC17A5) functions as a nitrate transporter in the plasma membrane. Proc Natl Acad Sci U S A 109 13434-13439.

Raat, N. J., Noguchi, A.C., Liu, V. B., Raghavachari, N., Liu, D., Xu, X., et al. (2009). Dietary nitrate and nitrite modulate blood and organ nitrite and the cellular ischemic stress response. Free Radic Biol Med 47, 510-517.

Radi, R., Beckman, J. S., Bush, K. M., \& Freeman, B.A. (1991). Peroxynitrite-induced membrane lipid peroxidation: the cytotoxic potential of superoxide and nitric oxide. Arch Biochem Biophys 288, 481-487.

Rassaf, T., Bryan, N. S., Maloney, R. E., Specian, V., Kelm, M., Kalyanaraman, B., et al. (2003) NO adducts in mammalian red blood cells: too much or too little? Nat Med 9 , $481-482$.

Rassaf, T., Flogel, U., Drexhage, C., Hendgen-Cotta, U., Kelm, M., \& Schrader, J. (2007). Nitrite reductase function of deoxymyoglobin: oxygen sensor and regulator of cardiac energetics and function. Circ Res 100, 1749-1754.

Reichert, E. T., \& Mitchell, S. W. (1880). On the physiological action of potassium nitrite Am J Med Sci 159, 158-180.

Rhodes, P., Leone, A.M., Francis, P. L., Struthers, A.D., Moncada, S. \& Rhodes, P.M. (1995) The L-arginine:nitric oxide pathway is the major source of plasma nitrite in fasted humans. Biochem Biophys Res Commun 209, 590-596.

Rodriguez, J., Maloney, R. E., Rassaf, T., Bryan, N. S., \& Feelisch, M. (2003). Chemical nature of nitric oxide storage forms in rat vascular tissue. Proc Natl Acad Sci U S A 100 336-341.

Rubbo, H., Radi, R., Trujillo, M., Telleri, R., Kalyanaraman, B., Barnes, S., et al. (1994). Nitric oxide regulation of superoxide and peroxynitrite-dependent lipid peroxidation. Formation of novel nitrogen-containing oxidized lipid derivatives. J Biol Chem 269 26066-26075

Sage, P. R., de la Lande, I. S., Stafford, I., Bennett, C. L., Phillipov, G., Stubberfield, J., et al. (2000). Nitroglycerin tolerance in human vessels: evidence for impaired nitroglycerin bioconversion. Circulation 102, 2810-2815.

Salas-Salvado, J., Bullo, M., Estruch, R., Ros, E., Covas, M. I., Ibarrola-Jurado, N., et al. (2014) Prevention of diabetes with Mediterranean diets: a subgroup analysis of a randomized trial. Ann Intern Med 160, 1-10.

Santamaria, P., Elia, A., Serio, F., \& Todaro, E. (1999). A survey of nitrate and oxalate content in fresh vegetables. J Sci Food Agric 79, 1882-1888.

Seljasen, R., Lea, P., Torp, T., Riley, H., Berentsen, E., Thomsen, M., et al. (2012). Effects of genotype, soil type, year and fertilisation on sensory and morphological attributes of carrots (Daucus carota L.). J Sci Food Agric 92, 1786-1799.

Shimokawa, H., Flavahan, N. A., \& Vanhoutte, P.M. (1991). Loss of endothelial pertussis toxin-sensitive $G$ protein function in atherosclerotic porcine coronary arteries. Circulation 83, 652-660.

Shiva, S., Huang, Z., Grubina, R., Sun, J. H., Ringwood, L. A., MacArthur, P. H., et al. (2007). Deoxymyoglobin is a nitrite reductase that generates nitric oxide and regulates mitochondrial respiration. Circ Res 100, 654-661.
Shiva, S., Rassaf, T., Patel, R. P., \& Gladwin, M. T. (2011). The detection of the nitrite reducatase and NO-generating properties of haemoglobin by mitochondrial inhibition. Cardiovasc Res 89, 566-573.

Shiva, S., Sack, M. N., Greer, J. J., Duranski, M., Ringwood, L. A., Burwell, L., et al. (2007). Nitrite augments tolerance to ischemia/reperfusion injury via the modulation of mitochondrial electron transfer. J Exp Med 204, 2089-2102.

Shiva, S., Wang, X., Ringwood, L. A., Xu, X., Yuditskaya, S., Annavajjhala, V., et al. (2006). Ceruloplasmin is a NO oxidase and nitrite synthase that determines endocrine NO homeostasis. Nat Chem Biol 2, 486-493.

Siddiqi, N., Neil, C., Bruce, M., MacLennan, G., Cotton, S., Papadopoulou, S., et al. (2014). Intravenous sodium nitrite in acute ST-elevation myocardial infarction: a randomized controlled trial (NIAMI). Eur Heart J 14(35 (19)), 1255-1262.

Sindler, A. L., Fleenor, B.S., Calvert, J. W., Marshall, K. D., Zigler, M. L., Lefer, D. J., et al. (2011). Nitrite supplementation reverses vascular endothelial dysfunction and large elastic artery stiffness with aging. Aging Cell 10, 429-437.

Sobko, T., Marcus, C., Govoni, M., \& Kamiya, S. (2010). Dietary nitrate in Japanese traditional foods lowers diastolic blood pressure in healthy volunteers. Nitric Oxide 22, 136-140.

Sparacino-Watkins, C. E., Lai, Y. -C., \& Gladwin, M. T. (2012). Nitrate-nitrite-nitric oxide pathway in pulmonary arterial hypertension therapeutics. Circulation 125, 2824-2826.

Srihirun, S., Sriwantana, T., Unchern, S., Kittikool, D., Noulsri, E., Pattanapanyasat, K., et al. (2012). Platelet inhibition by nitrite is dependent on erythrocytes and deoxygenation. PLoS One 7, e30380.

Szabo, C., Mitchell, J. A., Thiemermann, C., \& Vane, J. R. (1993). Nitric oxide-mediated hyporeactivity to noradrenaline precedes the induction of nitric oxide synthase in endotoxin shock. Br J Pharmacol 108, 786-792.

Szabo, C., Southan, G. J., \& Thiemermann, C. (1994). Beneficial effects and improved survival in rodent models of septic shock with S-methylisothiourea sulfate, a potent and selective inhibitor of inducible nitric oxide synthase. Proc Natl Acad Sci U S A 91, 12472-12476.

Tamme, T., Reinik, M., Roasto, M., Juhkam, K., Tenno, T., \& Kiis, A. (2006). Nitrates and nitrites in vegetables and vegetable-based products and their intakes by the Estonian population. Food Addit Contam 23, 355-361.

Tannenbaum, S. R., Weisman, M., \& Fett, D. (1976). The effect of nitrate intake on nitrite formation in human saliva. Food Cosmet Toxicol 14, 549-552.

Thomas, S. R., Davies, M. J., \& Stocker, R. (1998). Oxidation and antioxidation of human low-density lipoprotein and plasma exposed to 3-morpholinosydnonimine and reagent peroxynitrite. Chem Res Toxicol 11, 484-494

Torres, J., Sharpe, M.A., Rosquist, A., Cooper, C. E., \& Wilson, M. T. (2000). Cytochrome c oxidase rapidly metabolises nitric oxide to nitrite. FEBS Lett 475, 263-266.

Totzeck, M., Hendgen-Cotta, U. B., Luedike, P., Berenbrink, M., Klare, J. P., Steinhoff, H. J., et al. (2012). Nitrite regulates hypoxic vasodilation via myoglobin-dependent nitric oxide generation clinical perspective. Circulation 126, 325-334.

Totzeck, M., Hendgen-Cotta, U. B., Rammos, C., Petrescu, A.M., Meyer, C., Balzer, J., et al. (2012). Assessment of the functional diversity of human myoglobin. Nitric Oxide 26, 211-216.

Trichopoulou, A., Costacou, T., Bamia, C., \& Trichopoulos, D. (2003). Adherence to a Mediterranean diet and survival in a Greek population. N Engl J Med 348, 2599-2608.

Tricker, A.R. (1997). N-nitroso compounds and man: sources of exposure, endogenous formation and occurrence in body fluids. Eur J Cancer Prev 6, 226-268.

Tripatara, P., Patel, N. S., Webb, A., Rathod, K., Lecomte, F. M., Mazzon, E., et al. (2007). Nitrite-derived nitric oxide protects the rat kidney against ischemia/reperfusion injury in vivo: role for xanthine oxidoreductase. J Am Soc Nephrol 18, 570-580.

Tsuchiya, K., Kanematsu, Y., Yoshizumi, M., Ohnishi, H., Kirima, K., Izawa, Y., et al. (2005). Nitrite is an alternative source of NO in vivo. Am J Physiol Heart Circ Physiol 288, H2163-H2170.

Umbrello, M. Dyson, A., Bollen Pinto, B.,Fernandez, B. O., Simon, V., Feelisch, M., et al. (2014). Short-term hypoxic vasodilation in vivo is mediated by bioactive nitric oxide metabolites, rather than free nitric oxide derived from haemoglobinmediated nitrite reduction. J Physiol 592, 1061-1075.

van Faassen, E. E., Bahrami, S., Feelisch, M., Hogg N., Kelm, M., Kim-Shapiro, D. B., et al. (2009). Nitrite as regulator of hypoxic signaling in mammalian physiology. Med Res Rev 29, 683-741.

Vanhatalo, A., Bailey, S. J., Blackwell, J. R., DiMenna, F. J., Pavey, T. G., Wilkerson, D. P., et al. (2010). Acute and chronic effects of dietary nitrate supplementation on blood pressure and the physiological responses to moderate-intensity and incremental exercise. Am J Physiol Regul Integr Comp Physiol 299, R1121-R1131.

Vanhoutte, P.M. (2009). Endothelial dysfunction: the first step toward coronary arteriosclerosis. Circ J 73, 595-601.

Vanhoutte, I. M., \& Katusic, Z. S. (1988). Endothelium-derived contracting factor: endothelin and/or superoxide anion. Trends Pharmacol Sci 9, 229-230.

Vasquez-Vivar, J., Kalyanaraman, B., Martasek, P., Hogg, N., Masters, B.S., Karoui, H., et al. (1998). Superoxide generation by endothelial nitric oxide synthase: the influence of cofactors. Proc Natl Acad Sci U S A 95, 9220-9225.

Velmurugan, S., Kapil, V., Ghosh, S. M., Davies, S., McKnight, A., Aboud, Z., et al. (2013). Antiplatelet effects of dietary nitrate in healthy volunteers: involvement of cGMP and influence of sex. Free Radic Biol Med 65, 1521-1532.

Visser, M., Paulus, W. J., Vermeulen, M.A.R., Richir, M. C., Davids, M., Wisselink, W., et al (2010). The role of asymmetric dimethylarginine and arginine in the failing heart and its vasculature. Eur J Heart Fail 12, 1274-1281.

Vleeming, W., van de Kuil, A., te Biesebeek, J.D., Meulenbelt, J., \& Boink, A. B. (1997). Effect of nitrite on blood pressure in anaesthetized and free-moving rats. Food Chem Toxicol $35,615-619$

Wagner, D. A., Young, V. R., Tannenbaum, S. R., Schultz, D. S., \& Deen, W. M. (1984). Mammalian nitrite biochemistry: metabolism and endogenous synthesis. IARC Sci Publ 57, 247-253. 
Wang, Y. -Y., Hsu, P. -K., \& Tsay, Y. -F. (2012). Uptake, allocation and signaling of nitrate. Trends Plant Sci 17, 458-467.

Wang, J., Krizowski, S., Fischer, K., Tejero, J., Zhao, X., Ling Wang, L., et al. (2011). Sulfite oxidase: a novel nitrite reductase that generates nitric oxide. Free Radic Biol Med 51, S164.

Ward, M. H., de Kok, T. M., Levallois, P., Brender, J., Gulis, G., Nolan, B. T., et al. (2005). Workgroup report: drinking-water nitrate and health - recent findings and research needs. Environ Health Perspect 113, 1607-1614.

Webb, A., Bond, R., McLean, P., Uppal, R., Benjamin, N., \& Ahluwalia, A. (2004). Reduction of nitrite to nitric oxide during ischemia protects against myocardial ischemiareperfusion damage. Proc Natl Acad Sci U S A 101, 13683-13688.

Webb, A. J., Milsom, A. B., Rathod, K. S., Chu, W. L., Qureshi, S., Lovell, M. J., et al. (2008). Mechanisms underlying erythrocyte and endothelial nitrite reduction to nitric oxide in hypoxia: role for xanthine oxidoreductase and endothelial nitric oxide synthase. Circ Res 103, 957-964.

Webb, A. J., Patel, N., Loukogeorgakis, S., Okorie, M., Aboud, Z., Misra, S., et al. (2008). Acute blood pressure lowering, vasoprotective, and antiplatelet properties of dietary nitrate via bioconversion to nitrite. Hypertension 51, 784-790.

Wilcox, J. N., Subramanian, R. R., Sundell, C. L., Tracey, W. R., Pollock, J. S., Harrison, D.G., et al. (1997). Expression of multiple isoforms of nitric oxide synthase in normal and atherosclerotic vessels. Arterioscler Thromb Vasc Biol 17, 2479-2488.
Wood, K. C., Cortese-Krott, M. M., Kovacic, J. C., Noguchi, A., Liu, V. B., Wang, X., et al. (2013). Circulating blood endothelial nitric oxide synthase contributes to the regulation of systemic blood pressure and nitrite homeostasis. Arterioscler Thromb Vasc Biol 33, 1861-1871.

World Health Organization (2011). Global status report on non-communicable diseases 2010. (Geneva).

Wotherspoon, F., Browne, D. L., Meeking, D. R., Allard, S. E., Munday, L. J., Shaw, K. M., et al. (2005). The contribution of nitric oxide and vasodilatory prostanoids to bradykininmediated vasodilation in Type 1 diabetes. Diabet Med 22, 697-702.

Wylie, L. J., Kelly, J., Bailey, S. J., Blackwell, J. R., Skiba, P. F., Winyard, P. G., et al. (2013). Beetroot juice and exercise: pharmacodynamic and dose-response relationships. J Appl Physiol 115, 325-336.

Yanagisawa, M., Kurihara, H., Kimura, S., Tomobe, Y., Kobayashi, M., Mitsui, Y., et al (1988). A novel potent vasoconstrictor peptide produced by vascular endothelia cells. Nature 332, 411-415.

Zou, M. H., Cohen, R., \& Ullrich, V. (2004). Peroxynitrite and vascular endothelial dysfunction in diabetes mellitus. Endothelium 11, 89-97. 